\title{
The impact of the Pacific Decadal Oscillation on springtime dust activity in Syria
}

\author{
Bing Pu ${ }^{1,2}$ and Paul Ginoux ${ }^{1,2}$ \\ ${ }^{1}$ Atmospheric and Oceanic Sciences Program, Princeton University, Princeton, New Jersey 08544, USA \\ ${ }^{2}$ NOAA Geophysical Fluid Dynamics Laboratory, Princeton, New Jersey 08540, USA \\ Correspondence to: Bing Pu (bing.pu@noaa.gov)
}

Received: 6 July 2016 - Published in Atmos. Chem. Phys. Discuss.: 11 August 2016

Revised: 7 October 2016 - Accepted: 14 October 2016 - Published: 31 October 2016

\begin{abstract}
The increasing trend of aerosol optical depth in the Middle East and a recent severe dust storm in Syria have raised questions as to whether dust storms will increase and promoted investigations on the dust activities driven by the natural climate variability underlying the ongoing human perturbations such as the Syrian civil war. This study examined the influences of the Pacific Decadal Oscillation (PDO) on dust activities in Syria using an innovative dust optical depth (DOD) dataset derived from Moderate Resolution Imaging Spectroradiometer (MODIS) Deep Blue aerosol products. A significantly negative correlation is found between the Syrian DOD and the PDO in spring from 2003 to 2015. High DOD in spring is associated with lower geopotential height over the Middle East, Europe, and North Africa, accompanied by near-surface anomalous westerly winds over the Mediterranean basin and southerly winds over the eastern Arabian Peninsula. These large-scale patterns promote the formation of the cyclones over the Middle East to trigger dust storms and also facilitate the transport of dust from North Africa, Iraq, and Saudi Arabia to Syria, where the transported dust dominates the seasonal mean DOD in spring. A negative PDO not only creates circulation anomalies favorable to high DOD in Syria but also suppresses precipitation in dust source regions over the eastern and southern Arabian Peninsula and northeastern Africa.

On the daily scale, in addition to the favorable large-scale condition associated with a negative PDO, enhanced atmospheric instability in Syria (associated with increased precipitation in Turkey and northern Syria) is also critical for the development of strong springtime dust storms in Syria.
\end{abstract}

\section{Introduction}

Dust aerosol is an important component in the climate system that can modify global and regional energy and water balances (e.g., Tegen et al., 1996; Miller and Tegen, 1998; Miller et al., 2004; Lau et al., 2009; Yue et al., 2010, 2011; Choobari et al., 2014; Huang et al., 2014). Dust particles interact with both solar and terrestrial radiation, modifying temperature profile and hydrological cycle, which impact regional and global climate. For instance, studies found that mineral dust influences the strength of the West African monsoon (e.g., Miller and Tegen, 1998; Miller et al., 2004; Yoshioka et al., 2007; Solmon et al., 2008, 2012; Mahowald et al., 2010; Strong et al., 2015) and Indian summer monsoonal rainfall (Vinoj et al., 2014; Jin et al., 2014, 2015, 2016; Solmon et al., 2015; Kim et al., 2016). Dust particles can also serve as ice cloud nuclei and influence the microphysical and macrophysical properties of the cloud (e.g., Levin et al., 1996; Rosenfeld et al., 1997; Wurzler et al., 2000; Nakajima et al., 2001; Bangert et al., 2012), including its droplet size, number concentration, lifetime, and albedo, and in turn affecting the regional radiative budget and hydrological cycle. Mineral dust also provides nutrients for ocean phytoplankton, affecting ocean productivity and therefore carbon and nitrogen cycles and ocean albedo (e.g., Fung et al., 2000; Shao et al., 2011). Strong dust storms also have severe social and health impacts (e.g., Morman and Plumlee, 2013), affecting public transportation and causing damage to the eye and lung.

The Middle East is one of the dustiest regions in the world, and recent studies suggest an increasing trend of aerosol optical depth (AOD) largely due to dust emission 
(e.g., Pozzer et al., 2015; Klingmüller et al., 2016). A oncein-ten-years severe dust storm recently occurred in Syria during 6-9 September 2015, and raised much attention. More than one thousand people in Syria were hospitalized due to breathing difficulties ${ }^{1}$. The causes of such a strong dust storm are not fully understood, but there have been speculations that the ongoing civil war in Syria is largely responsible for it. The argument is that crop fields were abandoned or destroyed by the war, so soil dust is easier to be uplifted by wind from these unprotected land fields. More importantly, will severe dust storms like the one above increase in the future?

Notaro et al. (2015) studied the dust activities over the Arabian Peninsula and related the increased dust activities during 2007-2013 to the persistent dry condition over the "Fertile Crescent" (namely Syria, Iraq, Israel, and Jordan) primarily caused by a combined effect of La Niña and a negative phase of the Pacific Decadal Oscillation (PDO). Associated with the drought is crop failure and increased dust activities over the Arabian Peninsula. While others, such as Chin et al. (2014) found that the positive trend of dust emission over the Middle East from 2000 to 2009 is related to increased surface wind speed, and Klingmüller et al. (2016) attributed the positive trend of aerosol optical depth over the region (mainly Saudi Arabia, Iraq, and Iran) from 2001 to 2012 to the combined effects of decreased precipitation and soil moisture over Iraq and adjacent areas and enhanced surface wind over the Africa Red Sea coastal area that increased dust emission.

The above studies suggested that remote sea surface temperature (SST), local precipitation, surface wind, and vegetation all influence the dust activities over the Middle East. Among these factors, the remote forcings (such as tropical Pacific SST) and the PDO not only affect the precipitation variations over the region but can also influence local circulation including near-surface winds, both of which influence dust emission. It is thus quite important to understand the influences of these low-frequency long-lasting forcings on dust activities underlying the ongoing human perturbations such as civil war, land use change, and anthropogenic emission.

In this paper we examine the influence of the PDO on the variations of dust activities in Syria from 2003 to 2015 using Moderate Resolution Imaging Spectroradiometer (MODIS) Deep Blue dust optical depth (DOD). Previous studies on the connection between the PDO and dust activities in the Arabian Peninsula mainly focus on precipitation (e.g., Notaro et al., 2015; Yu et al., 2015). Here we explore thoroughly how the PDO influences the key factors associated with the dust activities in Syria on the interannual and daily scales.

The following section presents the data and methodology used in the paper. The co-variations of DOD in Syria and PDO from 2003 to 2015 are presented in Sect. 3 and their

\footnotetext{
${ }^{1}$ https://www.washingtonpost.com/news/worldviews/wp/2015/ 10/07/syrias-war-helped-create-an-epic-dust-storm-scientists-say/
}

physical connections are analyzed in detail in Sect. 4. We also discussed the long-time connection (e.g., 1948-2015) between Syrian DOD and the PDO inferred from the reanalyses and observations in Sect. 4. In Sect. 5, we examined the key factors associated with strong spring dust events in Syria using daily reanalysis and observations. To what extent climate models can capture the connections between the PDO and Syrian dust activities is discussed using the Geophysical Fluid Dynamics Laboratory (GFDL) AM3 model in Sect. 6. Major conclusions are summarized in Sect. 7.

\section{Data and methodology}

\subsection{Satellite and observational datasets}

\subsubsection{Dust optical depth}

Daily and monthly dust optical depth data are derived from MODIS aerosol products retrieved using the Deep Blue (MDB2) algorithm, which employs radiance from the blue channels to detect aerosols over bright land surfaces (e.g., desert). Because surface reflectance is low at blue channels, increases of reflectance and spectral contrast indicate the presence of aerosols (Hsu et al., 2004, 2006). Ginoux et al. (2012) used collection 5.1 level 2 aerosol products from MODIS aboard the Aqua satellite to derive DOD. Here, both MODIS aerosol products (collection 6, level 2) from the Aqua and Terra platforms are used for cross-validation. Terra passes the Equator from north to south around 10:30 local time while Aqua passes the Equator from south to north around 13:30 local time. While the frequency of the maximum daily $10 \mathrm{~m}$ wind in Syria peaks in the afternoon, later than the passing time of both Terra and Aqua, the averaged maximum total wind speed is nearly evenly distributed over a day (Fig. S1 in the Supplement). Thus, the results from both platforms are likely to provide a more complete picture of dust activities than either one alone.

Aerosol products such as AOD, single scattering albedo, and the Angström exponent are first interpolated to a regular $0.1^{\circ}$ by $0.1^{\circ}$ grid using the algorithm described by Ginoux et al. (2010). The dust optical depth is then derived from AOD following the methods of Ginoux et al. (2012) with adaptions for the newly released MODIS Collection 6 aerosol products. To separate dust from other aerosols, we use the Ångström exponent, which has been shown to be highly sensitive to particle size (Eck et al., 1999) and single scattering albedo which is less than one for dust due to its absorption of solar radiation. Instead of using negative values of the Angström exponent as done by Ginoux et al. (2012), we use a continuous function relating the Ångström exponent to fine-mode aerosol optical depth established by Anderson et al. (2005; their Eq. 5) based on ground-based data. The DOD data are available from January 2003 to December 2015. 
Daily and monthly DOD indices are formed by averaging DOD data in Syria between $34-36.5^{\circ} \mathrm{N}$ and $36.5-41^{\circ} \mathrm{E}$ to characterize dust activities. The averaging area covers most of Syria. We also tested using a smaller averaging box (33.5$36^{\circ} \mathrm{N}, 36.5-39^{\circ} \mathrm{E}$ ) for the DOD index, and the results are similar.

\subsubsection{Precipitation}

Version 7 of Tropical Rainfall Measuring Mission (TRMM) Multi-satellite Precipitation Analysis (TMPA) daily product (3B42) is used. This product covers from $50^{\circ} \mathrm{S}$ to $50^{\circ} \mathrm{N}$ with a spatial resolution of $0.25^{\circ}$ by $0.25^{\circ}$ and is available from 1998 to present. Several important changes are applied to the version 7 product, including using additional satellite data such as early records of Microwave Humidity Sounder (MHS) and operational Special Sensor Microwave Imager (SSM/I) records, using a new infrared brightness temperature dataset before the start of the Climate Prediction Center (CPC) $4 \mathrm{~km}$ Merged Global IR dataset, using a single uniformly processed surface precipitation gauge analysis, using a latitude-band calibration scheme for all satellites, and adding output fields in the data files (Huffman and Bolvin, 2014).

Precipitation Reconstruction over Land (Chen et al., 2002; hereafter PRECL) from the National Oceanic and Atmospheric Administration (NOAA) is a global analysis available monthly from 1948 to present at a $1^{\circ}$ by $1^{\circ}$ resolution. The dataset is derived from gauge observations from the Global Historical Climatology Network (GHCN), version 2, and the Climate Anomaly Monitoring System (CAMS) datasets.

The monthly precipitation of the Climatic Research Unit (CRU) time series (TS) 3.23 (Harris et al., 2014) is also used as a supplement to the PRECL. CRU TS 3.23 dataset covers 1901-2014, with a spatial resolution of $0.5^{\circ}$ by $0.5^{\circ}$ over land (excluding Antarctica). The gridded data are based on the analysis of over 4000 individual weather station records.

\subsubsection{Temperature}

The Hadley Centre sea ice and sea surface temperature (HadISST) dataset (Rayner et al., 2003) from the UK Met Office is available monthly from 1870 to the present with a horizontal resolution of $1^{\circ}$ by $1^{\circ}$ grid. Monthly SST from HadISST and land surface temperature from CRU TS 3.23 $\left(0.5^{\circ}\right.$ by $\left.0.5^{\circ}\right)$ from 1948 to 2015 are used to examine temperature patterns associated with dust activities.

\subsubsection{Leaf area index (LAI)}

LAI characterizes the canopies of plants. It is defined as the one-sided green leaf area per unit ground area in broadleaf canopies and as half the total needle surface area per unit ground area in coniferous canopies. LAI at zero is considered as bare ground while around 10, dense forests. Monthly LAI is derived from the version 4 of Climate Data Record (CDR) of Advanced Very High Resolution Radiometer (AVHRR) surface reflectance (Claverie et al., 2014) and produced by NASA's Goddard Space Flight Center (GSFC) and the University of Maryland. The gridded monthly data are on a $0.05^{\circ}$ by $0.05^{\circ}$ horizontal resolution and are available from 1981 to present. A detailed discussion on the algorithm and evaluation of the dataset can be found by Claverie et al. (2016).

Monthly MODIS LAI level 4 data on the Aqua platform (MYD15A2) are also used for 2003-2015. The original data files were obtained via personal communication (Ranga Myneni and Taejin Park; Boston University, 2016) and then reprocessed to fill the missing data by Paul Ginoux. The horizontal resolution of the data is $0.1^{\circ}$ by $0.1^{\circ}$.

\subsection{Reanalyses}

Daily and monthly geopotential height, horizontal winds, and specific humidity from the National Centers for Environmental Prediction (NCEP)/National Center for Atmospheric Research (NCAR) reanalysis (Kalnay et al., 1996, hereafter NCEP1) from 1948 to 2015 are used. Its horizontal resolution is $2.5^{\circ}$ by $2.5^{\circ}$ and has 17 vertical levels from 1000 to $10 \mathrm{hPa}$, with 8 levels between 1000 and $300 \mathrm{hPa}$. This reanalysis is used primarily in this study due to its long record.

ERA-Interim (Dee et al., 2011) from the European Centre for Medium-Range Weather Forecasts (ECMWF) is a global reanalysis with a horizontal resolution of $\mathrm{T} 255$ (about $0.7^{\circ}$ or $80 \mathrm{~km}$ ) and 37 vertical levels, available from 1979 to present. Monthly and four (two) times daily analysis (forecast) variables are used. The time coverage of ERA-Interim is shorter than the NCEP1 but its high resolution supplements the latter. Monthly horizontal winds and geopotential heights are compared with the NCEP1 in the same period (1979-2015) and show similar features (see discussion in Sect. 3). Daily $10 \mathrm{~m}$ and $850 \mathrm{hPa}$ winds and forecast variables such as precipitation are used to investigate the key factors associated with dust activities.

\subsection{Climate indices}

The PDO and Niño 3.4 indices are downloaded from the website of NOAA Climate Prediction Center (http://www.esrl.noaa.gov/psd/data/climateindices/list/).

The monthly standardized PDO index is derived from the leading principal component of SST anomalies in the northern Pacific Ocean $\left(20^{\circ} \mathrm{N}\right)$. The monthly mean of global mean SST anomalies is removed in the PDO index; thus the influence of global warming is not included. The data are available from 1948 to present. The monthly Niño 3.4 index is derived from the extended reconstructed sea surface temperature (ERSST v4; Huang et al., 2015, 2016; Liu et al., 2015) averaged over the tropical Pacific between $5^{\circ} \mathrm{N}-5^{\circ} \mathrm{S}$ and $120-170^{\circ} \mathrm{W}$ and is available from 1950 to present. 


\subsection{Model output}

To examine the relationship between the Syrian dust activities and the PDO, the output from the atmospheric component (AM3) of a general circulation model (CM3; Donner et al., 2011) developed at the GFDL is used. The finitevolume algorithms described in Lin and Rood $(1996,1997)$ and Lin $(1997,2004)$ are used in the dynamic core in AM3. Different from earlier versions of the model, a general curvilinear coordinate system is used and has largely improved the computational efficiency. A hybrid vertical coordinate (Simmons and Burridge, 1981) of 48 layers is used, with the top model layer at about $1 \mathrm{~Pa}(\sim 86 \mathrm{~km})$. AM3 calculates the mass distribution and optical properties of aerosols according to their emission, chemical production, transport, and dry and wet deposition. The dust source function follows the scheme of Ginoux et al. (2001), which places preferential sources in topographic depressions. The simulated aerosol optical depth and co-albedo show improved correlations with the AErosol RObotic NETwork (AERONET) station observations than earlier version of the model (CM2.1) but slightly underestimate AOD in the Middle East.

A historical run is conducted using the observed monthly SSTs from the Hadley Centre to drive the AM3. The simulated wind is nudged toward the NCEP/NCAR reanalysis with a relaxation timescale of $6 \mathrm{~h}$ (Moorthi and Suarez, 1992), similar to the method used by Li et al. (2008). A moderate horizontal resolution of $2^{\circ}$ by $2.5^{\circ}$ is used. The simulation was conducted from 1948 to 2010. Results from 1960 to 2010 are presented. The simulation provides a slightly longer time series, compared to the satellite data, to examine the relationship between Syrian DOD activities and the PDO.

\section{The co-variations between springtime DOD in Syria and the PDO during 2003-2015}

Notaro et al. (2015) related low-frequency variations of monthly precipitation over Syria and Iraq to the El NiñoSouthern Oscillation (ENSO) and the PDO and thus built the connection between dust activities and Pacific SSTs. Here we focus on Syria. Figure 1 shows the time series of monthly Syrian DOD indices (seasonal cycle removed) from both MODIS Aqua (green) and Terra (grey) platforms and the negative PDO index from January 2003 to December 2015. The variations of the DOD and the negative PDO indices are quite similar, showing strong decadal variations underlying interannual variations. Both are relatively weak during 20032007, relatively strong during 2007-2012 and have become relatively weak since 2013. Note that the DOD indices increase again in 2015 in association with the severe dust storm in September. The correlation between monthly DOD indices and the PDO index is -0.51 (Aqua) and -0.50 (Terra) from 2003 to 2015. Other indices, such as Niño 3.4 and Syrian LAI

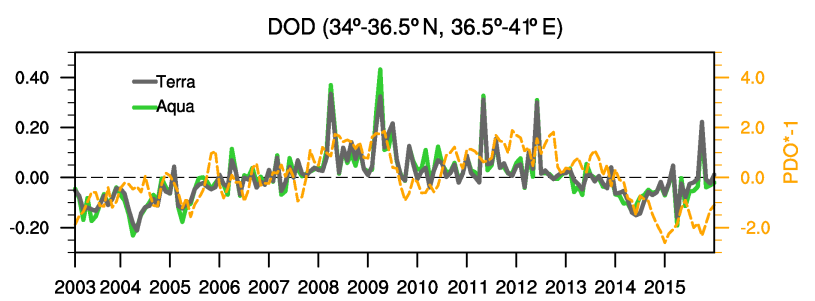

Figure 1. Monthly time series of Aqua (green) and Terra (grey) DOD indices averaged over Syria (see Fig. 2 for domain) and PDO index (orange; multiplying by -1 to show its negative correlation with the DOD indices).

also have significant but lower correlations with the DOD indices (Table 1).

ENSO is known to influence precipitation over the Middle East, by decreasing precipitation in La Niña years and increasing precipitation in El Niño years (e.g., Price et al., 1998; Mariotti et al., 2005; Mariotti, 2007, Chakraborty et al., 2006; Barlow et al., 2002; Wang et al., 2014; Yu et al., 2015; Banerjee and Kumar, 2016), and its influence is generally stronger in La Niña years (e.g., Wang et al., 2014). Previous studies also showed a comparable influence of the PDO on precipitation over the "Fertile Crescent" region including Syria and Iraq vs. that by ENSO (correlations of 0.52 vs. -0.57 from 1979 to 2013 , Notaro et al., 2015). The correlations in this study indicate that the PDO plays a greater role than ENSO in modulating dust activities in Syria in the recent decade. The PDO is not completely independent of ENSO, but can be viewed as a phenomenon driven by multiple physical processes, including the tropical Pacific SST, atmospheric noise, Aleutian low, KuroshioOyashio Extension, Pacific-North American pattern, Rossby wave breaking, etc. (e.g., Evans et al., 2001; Newman et al., 2003; Schneider and Cornuelle, 2005; Strong and Magnusdottir, 2009; Mills and Walsh, 2013). While some modeling studies suggested that up to half of the variance of the PDO can be explained by ENSO (e.g., Alexander et al., 2002; Liu and Alexander, 2007), others found that certain parts of extra-tropical Pacific SST variability are totally independent of ENSO (e.g., Zhang et al., 1997; Deser and Blackmon, 1995; Zhang and Delworth, 2015). Here the correlation between the monthly PDO and Niño 3.4 indices is 0.63 from January 2003 to December 2015, suggesting that statistically the Niño 3.4 index explains about $40 \%$ of the variances of the PDO index.

Figure 2 shows the correlation between the PDO index and Aqua and Terra DODs in spring, along with correlations between the Syrian DOD indices and PDO index in individual months and as an annual mean from 2003 to 2015. The correlation pattern between the PDO index and Aqua DOD is very similar to that associated with Terra DOD (Fig. 2a-b), with negative correlations over most areas of Syria and a stronger correlation over eastern Syria than the western part. DOD 
Table 1. Correlations between monthly DOD indices and the PDO, Niño 3.4 indices, precipitation from the CRU TS3.23 (P1; $2003-2014$ ) and PRECL (P2), AVHRR LAI (LAI1), MODIS Aqua LAI (LAI2) and $10 \mathrm{~m}$ wind speed from the ERA-Interim averaged over Syria (see the box in Fig. 2) for all the months (seasonal cycles are removed) from 2003 to 2015 (or 2014). Coefficients significant at the $95 \%$ confidence level are in bold.

\begin{tabular}{lrrrrrrr}
\hline & PDO & Niño 3.4 & P1 & P2 & LAI1 & LAI2 & $10 \mathrm{~m}$ wind \\
\hline Aqua DOD & $\mathbf{- 0 . 5 1}$ & $\mathbf{- 0 . 2 4}$ & -0.05 & -0.05 & $\mathbf{- 0 . 3 5}$ & $\mathbf{- 0 . 4 1}$ & -0.00 \\
Terra DOD & $\mathbf{- 0 . 5 0}$ & $\mathbf{- 0 . 2 3}$ & -0.05 & -0.06 & $\mathbf{- 0 . 3 2}$ & $\mathbf{- 0 . 3 9}$ & -0.02 \\
\hline
\end{tabular}

(a) Corr. PDO and DOD (Aqua) MAM

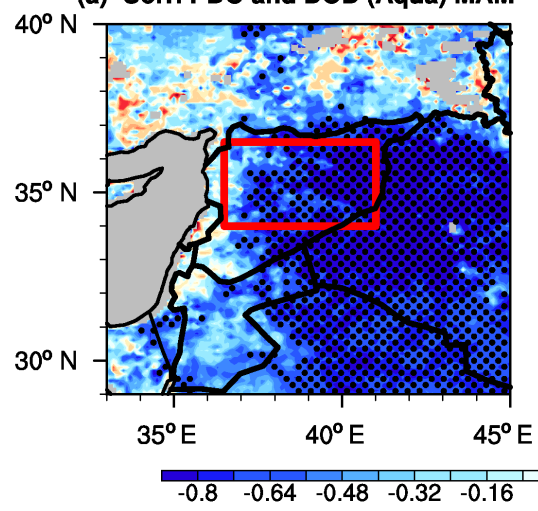

(b) Corr. PDO and DOD (Terra) MAM

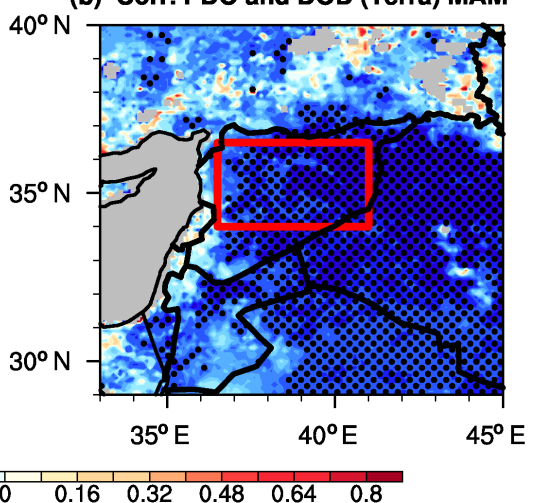

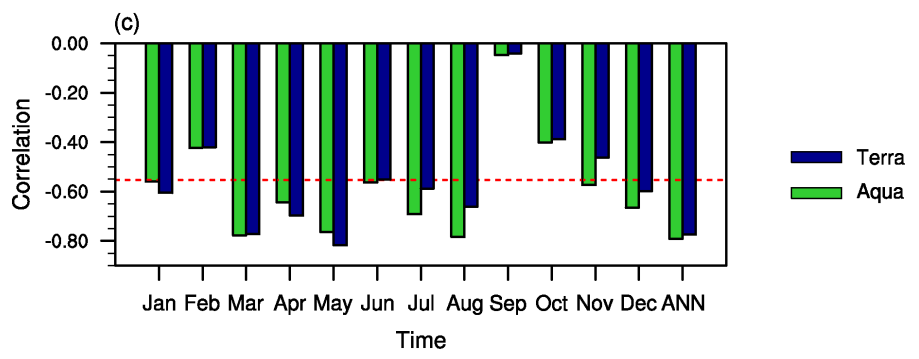

Figure 2. Correlation between the PDO index and MODIS (a) Aqua and (b) Terra DOD in MAM from 2003 to 2015. (c) Correlation between Syrian DOD indices (navy and green bars denote Terra and Aqua, respectively) and PDO index for each month and annual mean (ANN) from 2003 to 2015. Red dashed lines denote the $95 \%$ confidence level ( $t$ test). Red box denotes the averaging area for Syrian DOD index.

over Iraq and northern Saudi Arabia is also significantly negatively correlated with the PDO. The correlation between the monthly PDO and Syrian DOD indices shows a persistent negative relationship through the year, with higher correlations during March-April-May and also in July-August and December (Fig. 2c). The low correlation in September is due to the severe dust storm in 2015. The seasonal mean correlations between the DOD indices and the PDO index in MAM are -0.90 for both the Aqua DOD and Terra DOD indices, again much higher than their correlations with other indices (Table 2).

The connection between the Syrian DOD and PDO is further examined in Fig. 3, which shows the correlations between the Syrian DOD indices and SST and land surface temperatures during MAM and on the annual mean, along with SST and land surface temperature patterns associated with the PDO index. As shown in Fig. 3a-b, the SST pat- tern associated with the positive phase of the PDO in spring is quite similar to that in the annual mean, with anomalous warm SST over the tropical Pacific and along the east basin of the North Pacific and anomalous cold SST over the subtropical central to western North Pacific. SST in the Indian Ocean is also positively associated with the PDO. But the correlation between land surface temperature and the PDO is not significant in most regions, including the Arabian Peninsula.

Correlations between Aqua DOD index and SST in MAM are nearly opposite to those of the PDO, with negative correlations over the tropical and eastern Pacific but positive correlations over the central North Pacific (Fig. 3c). Correlations between the annual mean Aqua DOD index and SST and land surface temperature are similar to that in spring, but with slightly weaker magnitude over the central Pacific (Fig. 3d). The temperature patterns correlated with the Terra DOD in- 
Table 2. Same as Table 1 but for MAM average from 2003 to 2015 (or 2014). Coefficients significant at the $95 \%$ confidence level are in bold.

\begin{tabular}{lrrrrrrr}
\hline & PDO & Niño 3.4 & P1 & P2 & LAI1 & LAI2 & $10 \mathrm{~m}$ wind \\
\hline Aqua DOD & $\mathbf{- 0 . 9 0}$ & $\mathbf{- 0 . 6 0}$ & -0.14 & -0.38 & $\mathbf{- 0 . 6 0}$ & $\mathbf{- 0 . 6 4}$ & 0.31 \\
Terra DOD & $\mathbf{- 0 . 9 0}$ & $\mathbf{- 0 . 6 0}$ & -0.10 & -0.34 & $\mathbf{- 0 . 5 7}$ & $\mathbf{- 0 . 6 1}$ & 0.30 \\
\hline
\end{tabular}

(a) Corr. PDO and $\mathrm{T}_{s}$ (MAM)

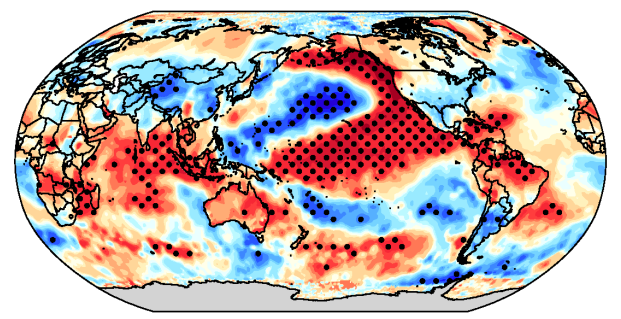

(c) Corr. Aqua DOD and $\mathrm{T}_{s}$ (MAM)

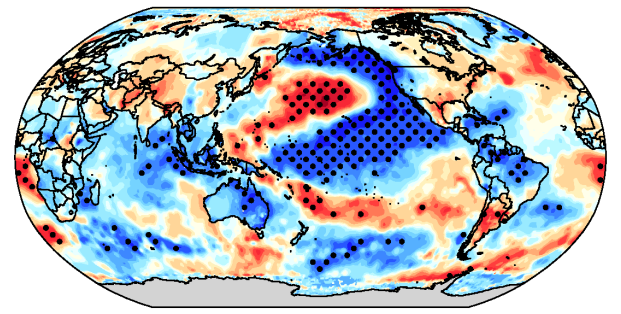

(e) Corr. Terra DOD and $\mathrm{T}_{s}$ (MAM)

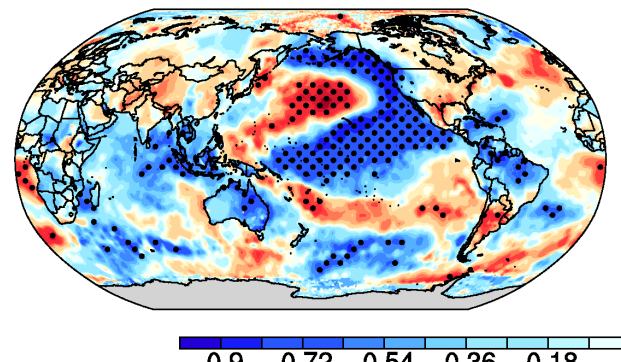

(b) Corr. PDO and $\mathrm{T}_{\mathrm{s}}$ (ANN)

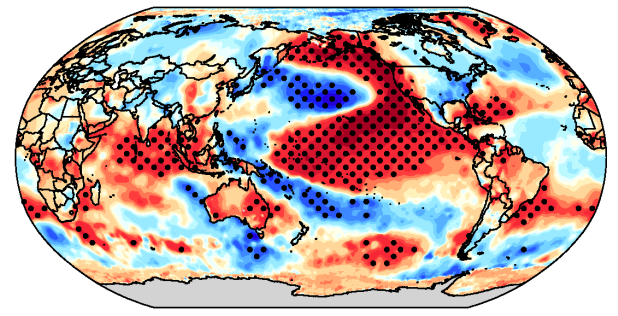

(d) Corr. Aqua DOD and $\mathrm{T}_{\mathrm{s}}$ (ANN)

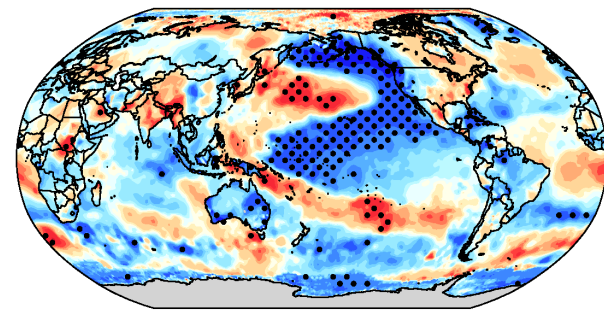

(f) Corr. Terra DOD and $T_{s}$ (ANN)

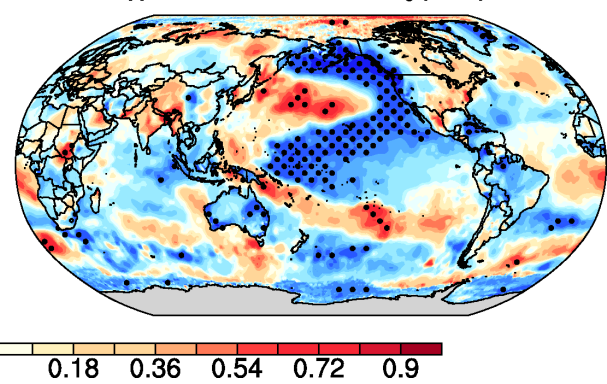

Figure 3. Correlation between the PDO index and HadISST (over the ocean) and CRU TS3.23 near-surface temperature (over land) for (a) MAM and (b) annual mean during 2003-2014. Correlation between (c)-(d) Aqua and (e)-(f) Terra DOD indices, and HadISST and CRU near-surface temperature for (c), (e) MAM and (d), (f) annual mean during 2003-2014. Areas significant at the $95 \%$ confidence level $(t$ test) are dotted.

dex are quite similar to that of Aqua DOD index (Fig. 3ef). Neither DOD indices are significantly correlated with the land surface temperature over the Middle East in spring.

Since Figs. 2 and 3 indicate a stronger negative correlation between the PDO and Syrian DOD index during MAM than on annual mean or other seasons, the following analysis focuses on their connections in spring. Spring is also the time when Syrian DOD is high and dust storms are most active (Figs. S2 and 3 in the Supplement).

\section{How does the PDO affect Syrian dust activities in spring?}

In this section we explore the mechanisms underlying the strong negative correlations between the PDO and Syrian DOD indices. Since MODIS DOD only covers the recent decade and the PDO has low-frequency decadal variations with cycles of about 15-25 and 50-70 years (e.g., Minobe, 1997; Mantua and Hare, 2002), it is difficult to assess their long-term (i.e., beyond the recent decade) relationship directly. We tried a method to indirectly verify their connections during 1948-2015 using high-quality reanalyses and observation. The PDO shows a dominant negative phase dur- 
ing the late 1940s to 1970 s, turns into a dominant positive phase during the 1980s and 1990s, and has become mostly negative again since the mid-2000s (e.g., JISAO/University of Washington website ${ }^{2}$ ). Therefore the NCEP1 reanalysis covers about one 50-70-year multi-decadal cycle of the PDO, while the EAR-Interim covers about half of the cycle.

We first compare the patterns of circulation and precipitation associated with DOD and PDO indices during 20032015 to identify key meteorological conditions associated with Syrian DOD activities and how these conditions are connected with the PDO. Then we compare the influences of the PDO on meteorological conditions during 2003-2015 to a longer period (e.g., 1948-2015). If the PDO shows relatively consistent influences on the meteorological conditions that are critical to Syrian DOD activities, then the influences of the PDO on Syrian DOD are also likely to persist during 1948-2015, assuming that the connection between Syrian DOD activities and those meteorological conditions does not change much during 1948-2015.

How does the PDO affect the circulation over the Middle East? Figure 4 shows the regression of $200 \mathrm{hPa}$ (contours) and $850 \mathrm{hPa}$ (shading) geopotential heights onto the standardized PDO and DOD indices. Figure 4a shows that in the positive phase of PDO, stationary waves propagate from the North Pacific through North America, the northern Atlantic, and Europe to the Middle East. The regressions at $850 \mathrm{hPa}$ are generally similar to those at $200 \mathrm{hPa}$, indicating an equivalent barotropic structure. Anomalous positive geopotential height over the Arabian Peninsula is associated with a positive PDO during 2003-2015 (Fig. 4a) and also during 1948-2015 (Fig. 4c). The geopotential height patterns associated with both the Aqua and Terra DOD indices are nearly opposite to those associated with the positive PDO index, with anomalous highs over the central North Pacific and northeastern North America and anomalous lows over the west coast of North America, Europe, and the Middle East (Fig. 4b, d).

Figure 4 suggests that the PDO can influence the variations of springtime DOD in Syria through its modification on the circulation over the Middle East. A negative PDO reduces the geopotential height both at 850 and $200 \mathrm{hPa}$ over the Arabian Peninsula, a scenario that favors high DOD in spring.

The connection between Syrian DOD and $850 \mathrm{hPa}$ winds and geopotential heights are further examined in Fig. 5. Figure 5a shows that a positive PDO is associated with anomalous easterly winds north of $40^{\circ} \mathrm{N}$, anomalous northerly winds over the central Mediterranean Sea around $15^{\circ} \mathrm{E}$, and weak southeasterly winds over the eastern Mediterranean Sea and western Syria, in the recent decade (Fig. 5a) as well as from 1948 to 2015 (Fig. 5c). Anticyclonic winds are located over Oman and Yemen at the south coast of Arabian Peninsula accompanied by an anomalous high. Positive geopotential height anomalies are also located over the northwestern

\footnotetext{
${ }^{2}$ http://research.jisao.washington.edu/pdo/graphics.html
}

Africa and East Africa. On the other hand, winds associated with high Syrian DOD indices are anomalous westerlies over the northern Mediterranean basin and Syria (Fig. 5b and d). Anomalous cyclonic flows are located over the southern Arabian Peninsula, nearly opposite to those associated with the positive phase of the PDO. The overall lower geopotential height over the Middle East and Africa also facilitates the formation of the cyclones (such as Sharav cyclones) that are important for the spring peak of dust storms in the northern Arabian Peninsula (e.g., Israelevich et al., 2003; Dayan et al., 2008, 2012).

The regression patterns of $850 \mathrm{hPa}$ winds and geopotential height onto the PDO and DOD indices in the ERA-Interim are generally consistent with those shown in the NCEP1 (Fig. S4).

Next we examine the associated variations of near-surface wind and precipitation that are tied to these geopotential height and low-level wind patterns. Figure 6 shows the regression of $10 \mathrm{~m}$ winds (vectors) and the cubic $10 \mathrm{~m}$ wind speed (shading) in the ERA-Interim onto standardized PDO index and onto the Aqua and Terra DOD indices. The ERAInterim is chosen here because of its higher horizontal resolution compared to the NCEP1, and thus is more suitable to examine surface wind variations associated with dust blasting in small scales. Cubic wind speed is used here as the classical dust emission scheme relates dust flux to the third power of $10 \mathrm{~m}$ horizontal winds. The patterns of the surface wind associated with the DOD indices (Fig. $6 \mathrm{~b}$ and d) are largely similar to that of winds at $850 \mathrm{hPa}$ (Figs. 5 and S4). Anomalous southwesterly winds from coastal North Africa and over the Mediterranean Sea tend to bring dust from North Africa to Syria. Such a route of dust transport has not been directly examined, but was discussed in back-trajectory studies on the airflow patterns onto Israel (e.g., Dayan, 1986). Earlier studies also have suggested a transport of dust from North Africa to the Mediterranean basin (e.g., D'Almeida, 1989; Moulin et al., 1998; Kubilay et al., 2000). Anomalous northerly flow over the Red Sea and the west coast of the Arabian Peninsula (and a weaker wind speed) and anomalous southerly flow (and a stronger wind speed) over the eastern peninsula also suggest a transport of dust from the source regions in the middle and southern Arabian Peninsula, e.g., An Nafud and Ad Dahna deserts, dry riverbeds such as Al Batin, Al-Rimah, and Al Sahba and Rub' al Khali sandy desert in Saudi Arabia (Ginoux et al., 2012). An Nafud and Ad Dahna deserts are major sources of dust storms in Saudi Arabia in spring to early summer (Notaro et al., 2013) and can also be an important source for Syrian DOD. A modeling study on the sources of spring DOD in Syria also confirms that North Africa (including Libya, Algeria, and Egypt) is the largest source with the secondary source in the Arabian Peninsula (Iraq and Saudi Arabia), and the overall transported DOD is much higher than local DOD in Syria in spring (Ginoux, 2015). 
(a) Reg. PDO and Z850 MAM (0315)

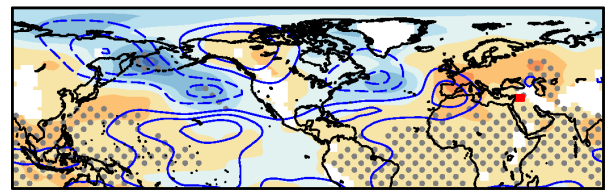

(c) Reg. PDO and Z850 MAM (4815)

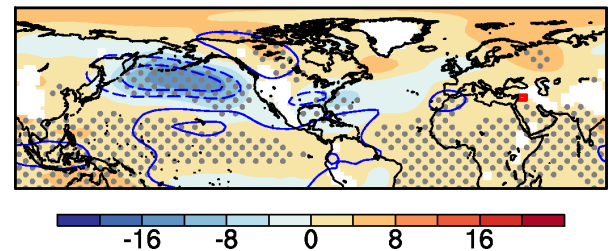

(b) Reg. Aqua dodidx and Z850 MAM (0315)

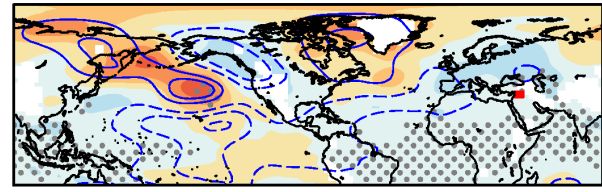

(d) Reg. Terra dodidx and Z850 MAM (0315)

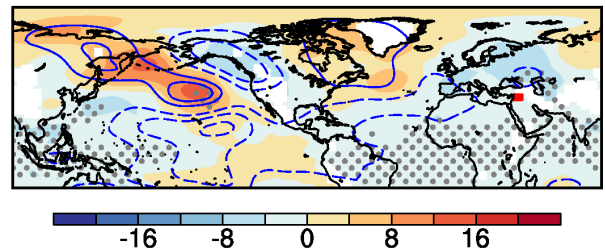

Figure 4. Regression of $850 \mathrm{hPa}$ (shading) and $200 \mathrm{hPa}$ (blue contours; solid lines for positive values and dashed lines for negative values, from -40 to $40 \mathrm{gpm}$ with an interval of $10 \mathrm{gpm}$, zero line is not shown) geopotential heights onto the standardized PDO index for (a) $2003-$ 2015 and (c) 1948-2015 and onto the standardized (b) Aqua and (d) Terra DOD indices. Areas significant at the $95 \%$ confidence level ( $t$ test) are dotted.

(a) Reg. stdPDO and UV850 MAM (0315)

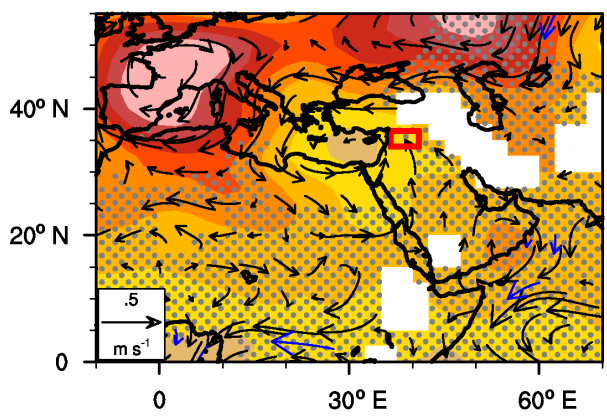

(c) Reg. stdPDO and UV850 MAM (4815)

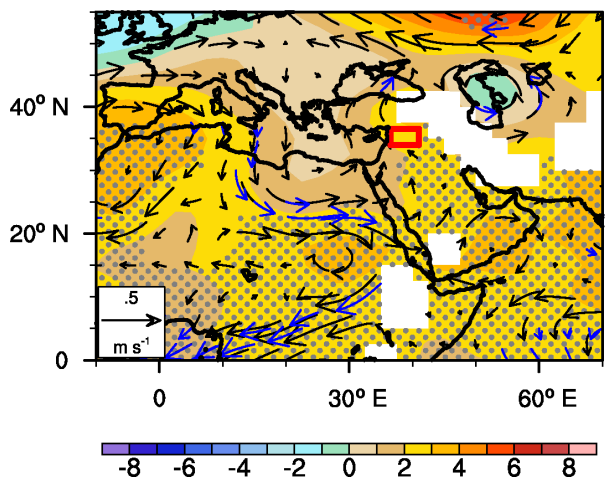

(b) Reg. Aqua DOD and UV850 MAM (0315)

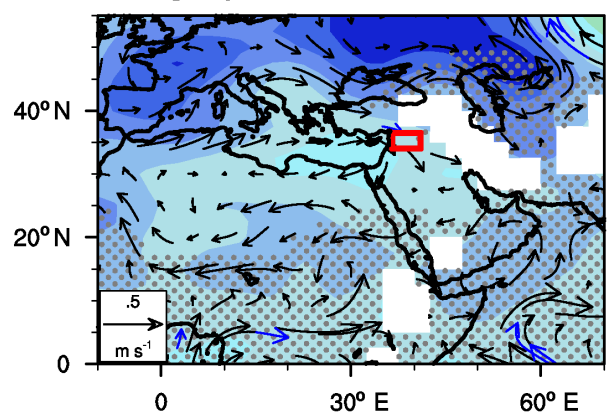

(d) Reg. Terra DOD and UV850 MAM (0315)

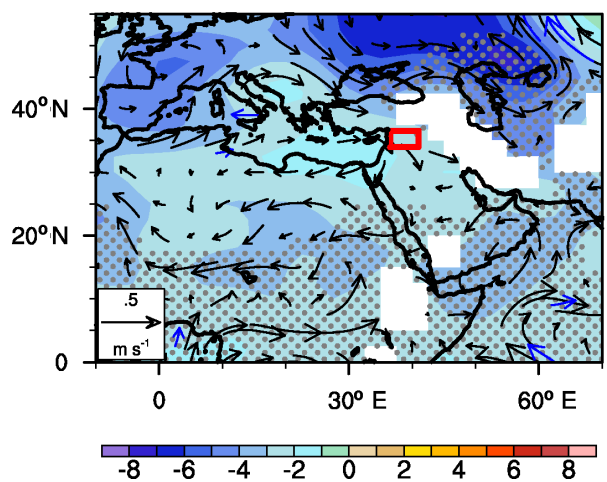

Figure 5. Regressions of NCEP1 $850 \mathrm{hPa}$ geopotential height (shading; gpm) and horizontal winds (vectors; $\mathrm{m} \mathrm{s}^{-1}$ ) onto the standardized PDO index during (a) 2003-2015 and (c) 1948-2015, and onto the standardized (b) Aqua and (d) Terra DOD indices during $2003-2015$. Area where the regression is significant at the $95 \%$ confidence level ( $t$ test) is dotted, and vectors significant at the $90 \%$ confidence level are plotted in blue.

Variations of surface wind associated with the PDO are different from that associated with high DOD, with nearly opposite patterns of cubic wind speeds over the Arabian Peninsula (Fig. 6a and c). When the PDO is positive, anomalous northerly winds pass through the Mediterranean Sea and turn into westerly over the northeastern Africa, which may bring dust from Africa to Israel, Jordan, and Syria as well as increase the moisture transport from the Mediterranean Sea (Fig. 6a). The anomalous southerly wind from the Red Sea also brings moisture onto Syria and tends to promote precipitation. Over southwestern Syria, the anomalous southerly wind is from the less dusty area over northwestern Saudi 
(a) Reg. stdPDO and V ${ }^{3}$ MAM (0315)

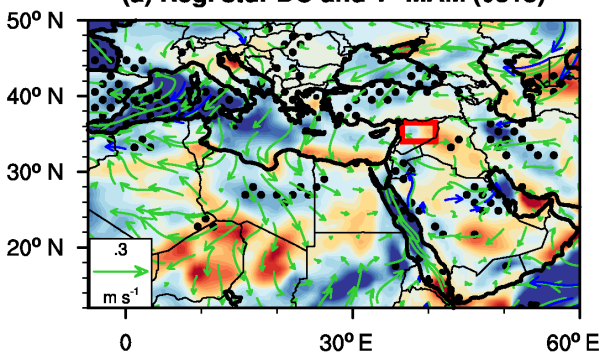

(c) Reg. stdPDO and V MAM (7915)

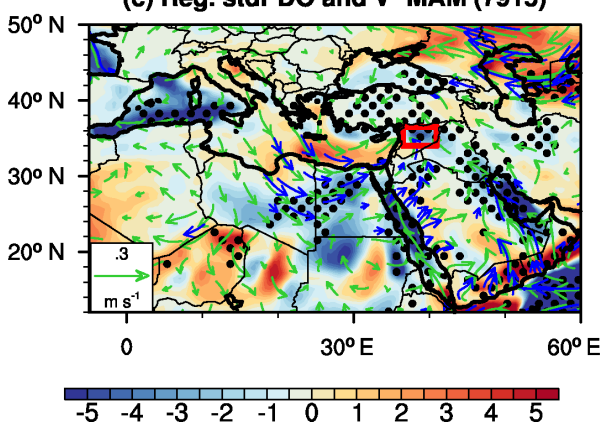

(b) Reg. Aqua dodidx and V ${ }^{3}$ MAM (0315)

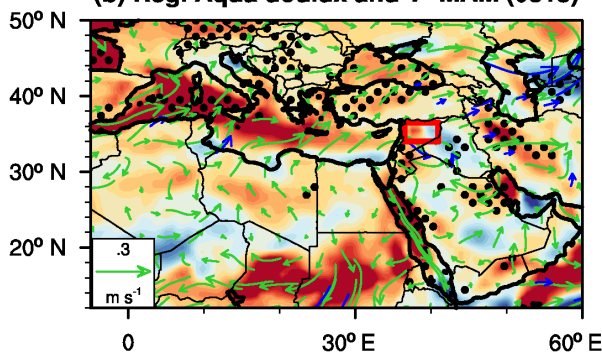

(d) Reg. Terra dodidx and $V^{3}$ MAM (0315)

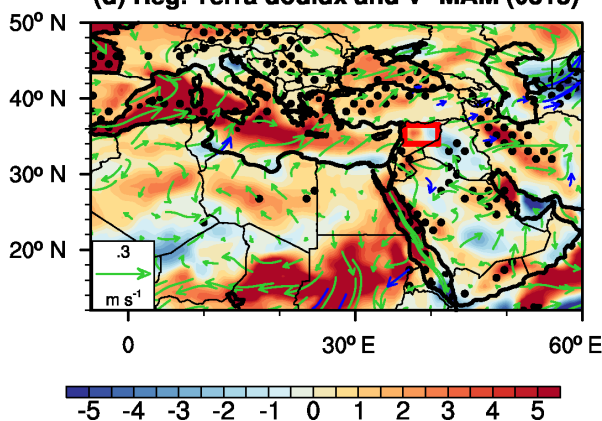

Figure 6. Regressions of ERA-Interim $10 \mathrm{~m}$ horizontal winds (green vectors; $\mathrm{m} \mathrm{s}^{-1}$ ) and cubic wind speed (shading; $\mathrm{m}^{3} \mathrm{~s}^{-3}$ ) onto a standardized PDO index (a) from 2003 to 2015 and (c) from 1979 to 2015 and onto the standardized (b) Aqua and (d) Terra DOD indices. Areas where the regressions of the wind speed are significant at the $95 \%$ confidence level are dotted and vectors significant at the $90 \%$ confidence level are plotted in blue ( $t$ test).

Arabia and is less likely to enhance Syrian DOD. A weak anomalously westerly flow over northeastern Saudi Arabia around $30^{\circ} \mathrm{N}$ and $45^{\circ} \mathrm{E}$ tends to block the northward transport of dust from the southern and middle Arabian Peninsula to Syria. This westerly flow weakens if extending the time period of regression to 1979 (Fig. 6c). A stronger anomalously westerly flow along the west coast of Saudi Arabia and a southerly flow from the south coast of the Arabian Peninsula are also found in association with the positive PDO during 1979-2015, bringing moisture onto Syria. The discrepancies between the regression patterns in the recent decade and those during 1979-2015, e.g., over the eastern Mediterranean Sea (Fig. 6a and c), are likely associated with the decadal variations of the PDO, indicating an instable connection between the PDO and surface winds in some areas.

The anomalous precipitation patterns correlated with the PDO and DOD indices are shown in Fig. 7. The PDO has a mild connection with precipitation over the Middle East in spring on the interannual timescale. Similar correlation patterns are found in previous studies that correlated the PDO with low-frequency (i.e., $>7$ years) variations of precipitation (e.g., Dai, 2013, Fig. 2c). A positive phase of the PDO is associated with increased precipitation over most areas of the Arabian Peninsula, Turkey, western Iran, and northeastern Africa over Libya and Egypt in the recent decade and during 1948-2015 (Fig. 7a and c). Patterns are similar during 1979-2015 (not shown). On the other hand, high DOD in Syria is associated with reduced precipitation over the Ara- bian Peninsula (particularly Iraq and central and southern Saudi Arabia), Egypt, eastern Algeria, and western Libya. This is consistent with Fig. 6, which indicates dust transport from these areas to Syria in the spring.

Figure 8 shows the vertically integrated mass-weighted moisture flux (vector) and its magnitude (shading) onto the standardized PDO and DOD indices in MAM from 2003 to 2015 and also onto the standardized PDO index during 1948-2015. Consistent with the precipitation regression patterns (Fig. 7), anomalous anticyclonic moisture flux brings more moisture onto the Arabian Peninsula from the Red Sea and Gulf of Aden associated with a positive PDO (Fig. 8a and c). Moisture flux over northeastern Africa is also enhanced. Conversely, high DOD in Syria is associated with an anomalous cyclonic flux centered over the south coast of the Arabian Peninsula, which reduces moisture flux onto the southern Arabian Peninsula (Fig. 8b and d). Moisture flux over northeastern Africa is also reduced, associated with an anomalous cyclonic flow over the Republic of the Sudan and Egypt. The pattern of the anomalous moisture fluxes associated with PDO and DOD indices are quite similar to that of the $850 \mathrm{hPa}$ winds (e.g., Fig. 5), indicating a dominant role played by low-level moisture transport.

These anomalous circulation and moisture flux patterns are also linked to the stability of the lower atmosphere. Figure 9 shows the regression of low-level moist static energy (MSE; integrated from surface to $700 \mathrm{hPa}$ ) onto the standardized PDO and DOD indices. MSE is defined as a sum 
(a) Corr. PDO and PRE MAM (0315)

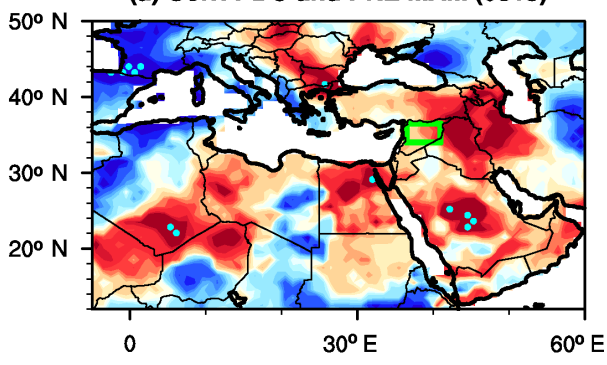

(c) Corr. PDO and PRE MAM (4815)

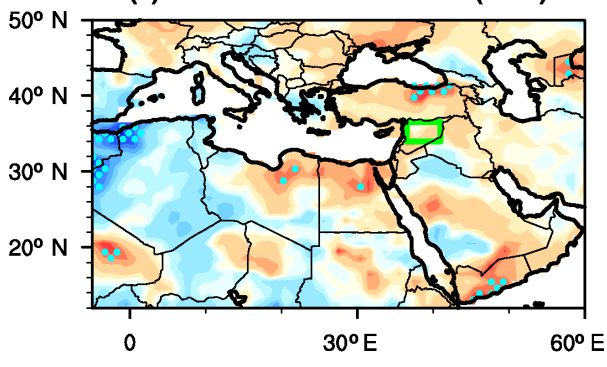

$\begin{array}{lllllllll}-0.45 & -0.3 & -0.15 & 0 & 0.15 & 0.3 & 0.45\end{array}$ (b) Corr. Aqua dodidx and PRE MAM

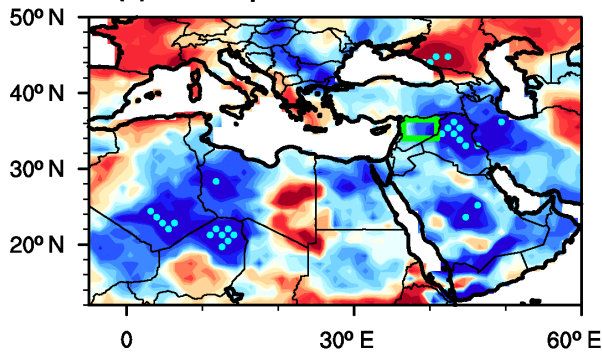

(d) Corr. Terra dodidx and PRE MAM

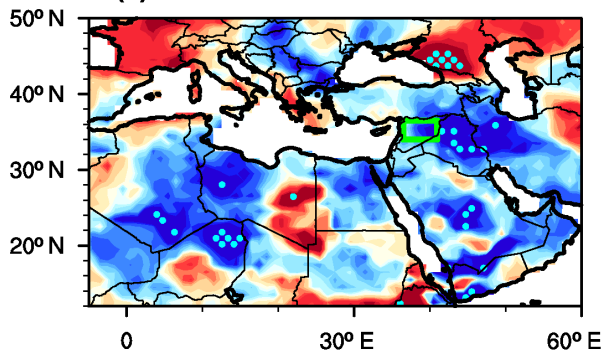

$\begin{array}{lllllll}-0.45 & -0.3 & -0.15 & 0 & 0.15 & 0.3 & 0.45\end{array}$

Figure 7. Correlation between PRECL precipitation and PDO index during (a) 2003-2015, (c) 1948-2015 and between precipitation and (b) Aqua and (d) Terra DOD indices during 2003-2015. Areas where the correlation coefficients are significant at the $95 \%$ confidence level ( $t$ test) are dotted.

(a) Reg. stdPDO and vintQV MAM (0315)

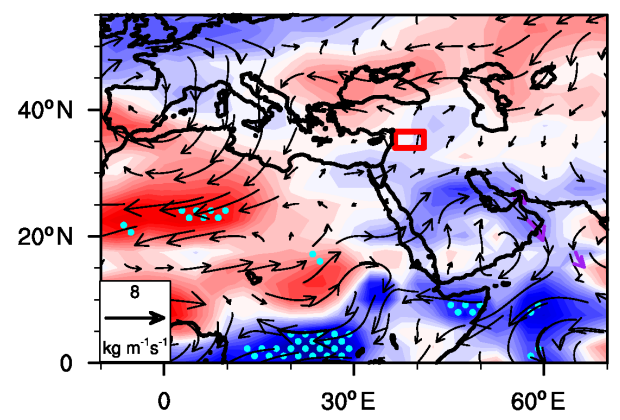

(c) Reg. stdPDO and vintQV MAM (4815)

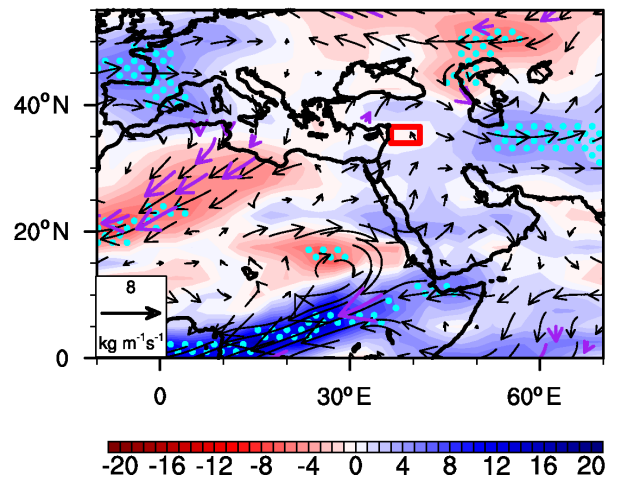

(b) Reg. Aqua dodidx and vintQV MAM

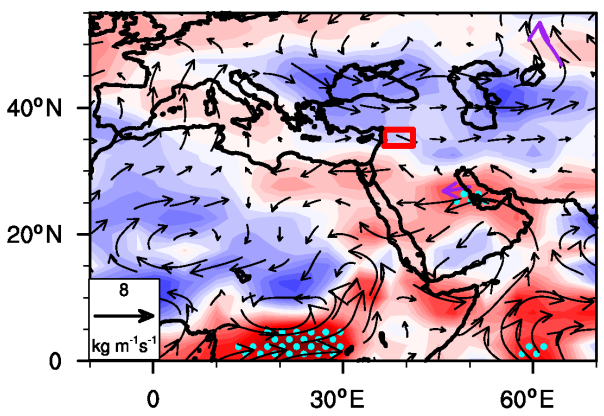

(d) Reg. Terra dodidx and vintQV MAM

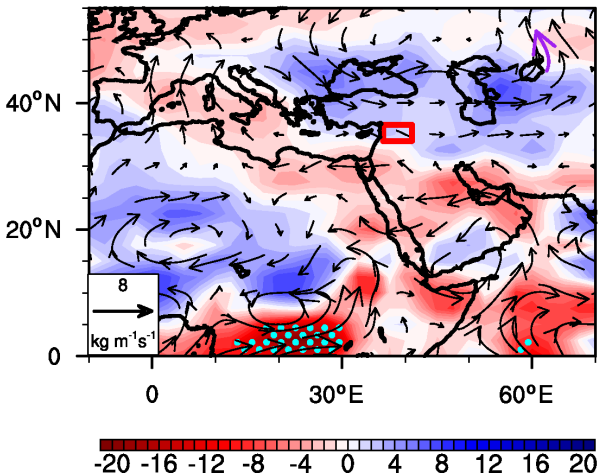

Figure 8. Regression of vertically integrated mass weighted monthly moisture flux (vectors; $\mathrm{kg} \mathrm{m}^{-1} \mathrm{~s}^{-1}$ ) and its magnitude (shading) onto standardized PDO index during (a) 2003-2015 and (c) 1948-2015, and onto the standardized (b) Aqua and (d) Terra DOD indices. Moisture flux is integrated from surface to $300 \mathrm{hPa}$. Areas with magnitude of moisture flux significant at the $90 \%$ confidence level are dotted, and moisture fluxes significant at the $90 \%$ confidence level are plotted in purple vectors ( $t$ test). 
(a) Reg. stdPDO and MSE MAM (0315)

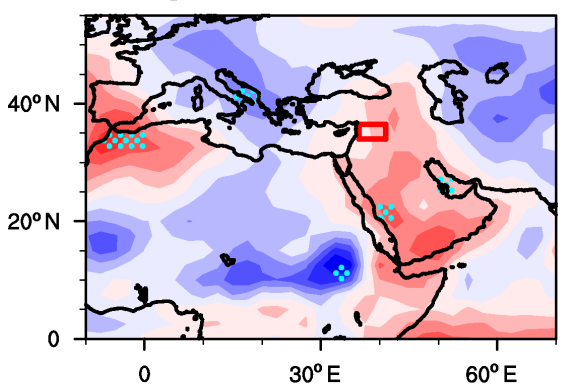

(c) Reg. stdPDO and MSE MAM (4815)

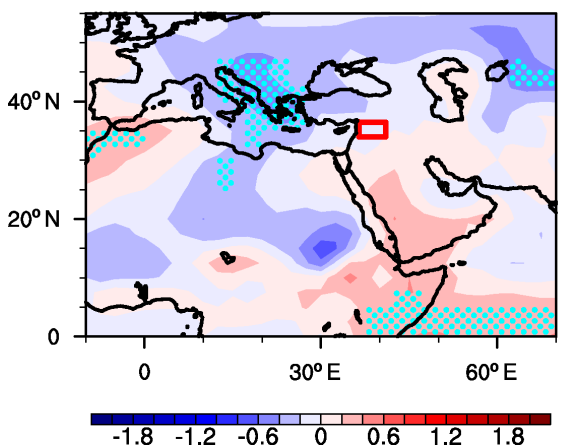

(b) Reg. Aqua dodidx and MSE MAM

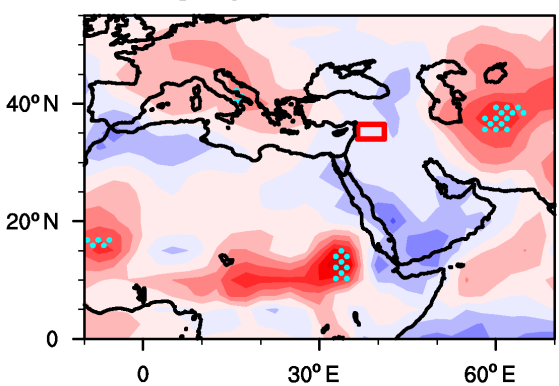

(d) Reg. Terra dodidx and MSE MAM

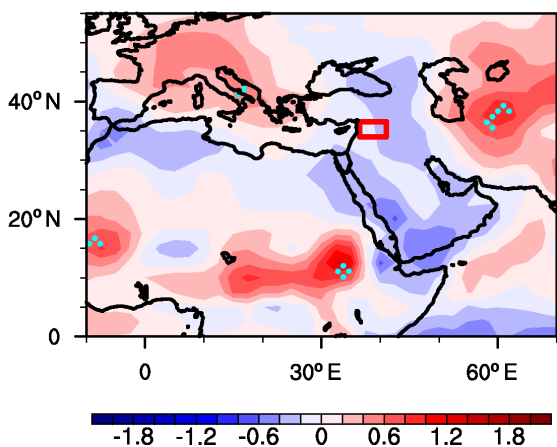

Figure 9. Regression of vertically integrated MSE $\left(10^{4} \mathrm{~J} \mathrm{~m}^{-2}\right)$ over the lowest four atmospheric layers $(1000,925,850$, and $700 \mathrm{hPa})$ from the NCEP1 onto the standardized PDO index for (a) 2003-2015 and (c) 1948-2015 and onto the standardized DOD indices from MODIS (b) Aqua and (d) Terra during 2003-2015. Areas significant at the $90 \%$ confidence level ( $t$ test) are dotted.

of sensible, latent, and geopotential energy in a column air, i.e., $\mathrm{MSE}=c_{p} T+L q+g z$, where $c_{p}$ is the specific heat of air at constant pressure, $T$ is air temperature, $L$ is the latent heat of vaporization of water, $q$ is specific humidity, $g$ is the gravity acceleration, and $z$ geopotential height. MSE increasing with altitude denotes a stable atmosphere, so high MSE in the lower atmosphere indicates an instable condition, and vice versa. The patterns of the anomalous MSE are tied to the changes of moisture flux and precipitation anomalies. Reduced MSE is located over large areas of the Arabian Peninsula, particularly the southwest coast, in association with high DOD in Syria, indicating a more stable low-level atmosphere and thus less precipitation (Fig. 9b and d). Such a low MSE is also found over North Africa, but in a weaker magnitude. The pattern associated with a positive PDO is nearly opposite, with increased low-level MSE over the Arabian Peninsula, Red Sea, and along the east coast of Egypt, denoting an instable atmosphere associated with anomalous moisture transport (Fig. 8a and c) and promoting convection and precipitation (Fig. 9a and c).

In short, Figs. 4-9 show spring circulation and precipitation patterns favorable to high DOD in Syria. Anomalous low pressure over Europe, the southern Arabian Peninsula, and northeastern to eastern Africa promotes westerly winds from North Africa and southerly flow over the southeastern Arabian Peninsula, both of which tend to transport dust to Syria. The anomalous moisture fluxes associated with the geopo- tential height and wind anomalies also favor a dry and stable condition over the dust source regions adjacent to Syria, such as Saudi Arabia, Iraq, and North Africa. The circulation and precipitation patterns associated with a positive PDO are largely opposite to those associated with high DOD in Syria in the recent decade, which explains the strong negative correlation between the two. Examination of circulation and precipitation variations associated with the PDO in a longer time period (either from 1979 to 2015 or 1948 to 2015) show generally similar patterns, but also with some discrepancies. If the conditions associated with high DOD in Syria are valid beyond the recent decade, i.e., 2003-2015, the negative role of the PDO on spring dust activities in Syria is also likely to persist.

\section{$5 \quad$ Analysis on strong dust storms in spring}

Severe dust storms usually only persist a few days or even a few hours (e.g., Haboobs), and seasonal or monthly averages reduce the variability of dust activities and may smooth out some important features. In this section we discuss the conditions associated with strong dust storms in Syria, using daily DOD and reanalysis variables, and compare these conditions with those from seasonal mean patterns discussed above including the teleconnections with the PDO. Composites are formed based on daily Syrian DOD index from Aqua. 
(a)

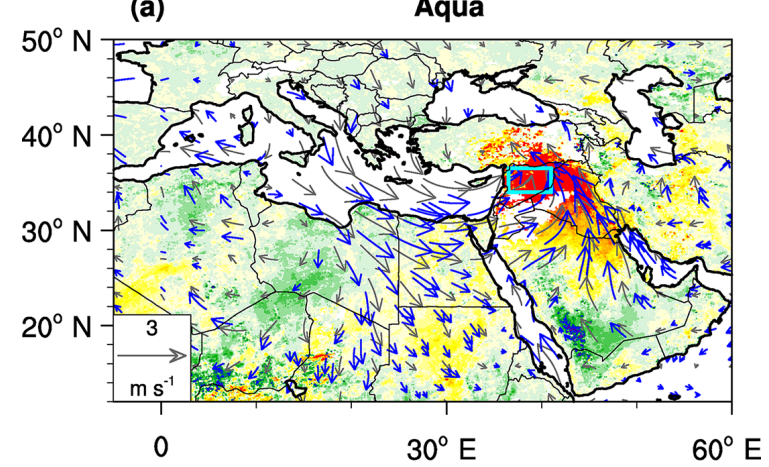

(b)

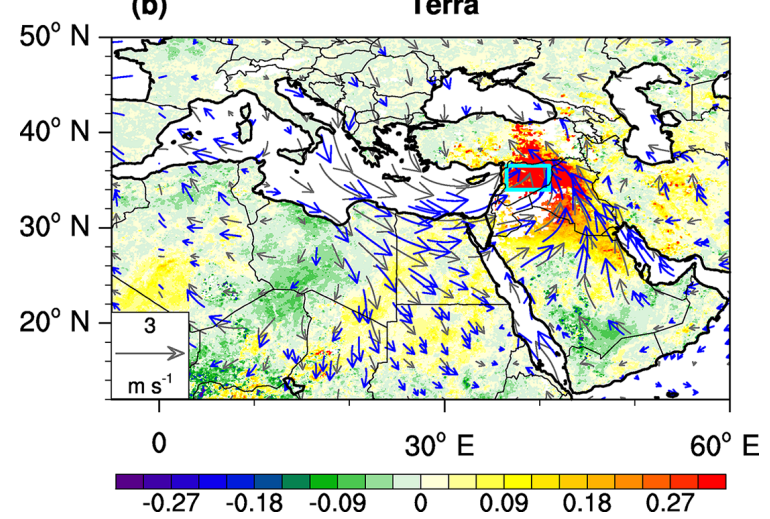

Figure 10. Composites of (a) Aqua and (b) Terra daily DOD (shading) along with ERA-Interim $10 \mathrm{~m}$ horizontal wind anomalies (with reference to the 1979-2015 mean; vectors) for days with Syrian DOD index (Aqua) greater than 1 standard deviation during MAM from 2003 to 2015. Shading shows values significant at the $95 \%$ confidence level over land, while wind vectors significant at the $95 \%$ confidence are plotted in blue ( $t$ test).

Days during March, April, and May from 2003 to 2015 are selected when the daily anomaly (with reference to long-term mean) of DOD index is greater than 1 standard deviation to form daily composites. Results are very similar but patterns are in slightly stronger (weaker) magnitudes if choosing the threshold of $1.5(0.5)$ standard deviations (not shown).

Figure 10 shows the composite of Aqua and Terra daily DOD (shading) and ERA-Interim $10 \mathrm{~m}$ winds based on the Aqua DOD index. The patterns are quite similar in Aqua and Terra DODs. DOD anomaly is above 0.3 over Syria and western Iraq (Fig. 10a-b). Anomalous high DOD is also located over eastern Saudi Arabia and the northeastern Africa, indicating a possible transport of dust from these areas to Syria. Anomalous cyclonic flow is centered over southern Turkey around $30^{\circ} \mathrm{E}$, with anomalous strong westerly wind blowing from North Africa and southerly flow from the eastern Arabian Peninsula, consistent with dust transport discussed in the above section. However, different from the seasonal mean regression patterns (e.g., Fig. 6), there are the anomalous southerly winds from the Red Sea and Persian Gulf.

Figure 11 shows the composite of daily precipitation from the ERA-Interim twice-daily forecast and TRMM daily precipitation for days with DOD anomaly above 1 standard deviation. Precipitation anomalies are shown in percentages (with reference to the climatological mean) instead of absolute values in order to highlight the precipitation variations over the Middle East, where the magnitude of precipitation in spring is quite low (less than $1 \mathrm{~mm} \mathrm{day}^{-1}$ in most of the areas). Patterns of precipitation anomalies associated with strong dust storms are quite similar in the ERA-Interim and TRMM. Precipitation increases significantly (more than $80 \%$ ) over Turkey and the northeastern Mediterranean, but decreases over the central and southern Arabian Peninsula and northeastern Africa. Syria sits in between the anomalous wet and dry regions, with slightly increased precipitation in its northern domain. These features are somewhat similar to the results of previous studies on strong dust storms and our understanding on the seasonal mean patterns associated with high DOD in Syria. Strong dust storms such as Haboobs (usually about $1 \mathrm{~km}$ height and tens to hundreds of kilometers in length) are usually associated with convective storms (e.g., Miller et al., 2008; Roberts and Knippertz, 2012; Vukovic et al., 2014; Dempsey, 2014). The cold downdraughts from convective storms spread out and can lift the dust from the surface to form a dusty towering "wall" as the front of a Haboob. Similarly, severe precipitation and convection in Turkey and northern Syria can produce an unstable atmospheric condition in the region, and the intensified low-level winds can lift dust from the surface and thus increase DOD. Reduced precipitation over the southern Arabian Peninsula and North Africa facilitates dust transport from these source areas to Syria.

Figure 12 shows composites for a vertically integrated mass weighted moisture flux (vectors) and its magnitude (shading) from the NCEP1 and convective available potential energy (CAPE) from the ERA-Interim for days with Aqua DOD anomaly greater than 1 standard deviation. Figure 12a shows an anomalous westerly flux from northern Egypt and a southerly flux from the Red Sea and Persian Gulf largely increase the moisture transport to Syria and eastern Turkey, while the reduced moisture fluxes along the south coast of Iran, southern Arabian Peninsula, southern Red Sea, and the Gulf of Aden are quite similar to those patterns associated with high Syrian DOD in spring (Fig. $8 \mathrm{~b}$ and d) and a negative PDO (i.e., opposite to Fig. 8c). Consistently, CAPE is increased over Turkey and Syria, indicating an unstable atmospheric condition associated with increased moisture transport to the region, while over the southern Arabian Peninsula and northeastern Africa where moisture flux is reduced, CAPE is decreased (Fig. 12b).

The connection between the PDO and daily strong dust storms is also verified by correlating an index of the occurrence of strong dusty events (i.e., daily DOD anomaly greater than 1 standard deviation) in MAM with HadISST from 2003 to 2015 (Fig. S5). 
(a)

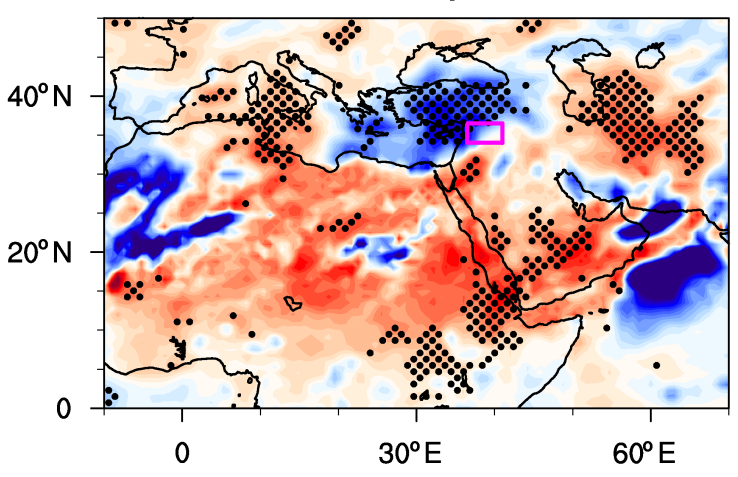

(b)

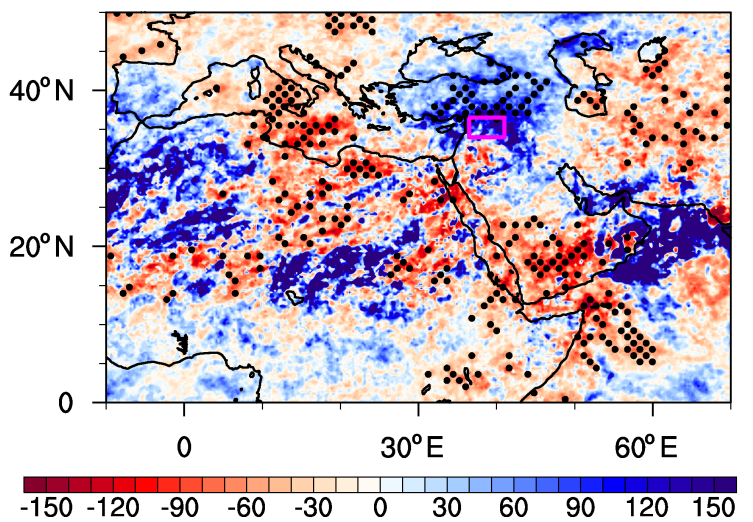

Figure 11. Composites of daily precipitation anomalies (shading; $\%$ with references to the climatology) from (a) the ERA-Interim and (b) TRMM for the days with Syrian DOD index (Aqua) greater than 1 standard deviation during MAM from 2003 to 2015. Areas significant at the $95 \%$ confidence level ( $t$ test) are dotted.

Figures 10-12 suggest that severe dust storms occur under both favorable large-scale and regional-scale features. Remote forcing such as PDO modifies springtime circulation and precipitation patterns. For example, a negative phase of PDO decreases precipitation over the southern Arabian Peninsula and northeastern Africa and favors the transport of dry dusty air from these regions to Syria, while strong convective storms over Turkey favor the dust lifting and the formation of strong dust storms in Syria.

\section{Can the recent GFDL climate model capture the connection between the PDO and Syrian DOD?}

To what extent can current climate model capture the connection between the PDO and Syrian DOD? We examined such relationships in the GFDL AM3 model. Figure 13a shows the correlation between a modeled DOD index and surface temperature from 1960 to 2010 in MAM. The correlation pattern over the North Pacific is quite similar to that of a negative PDO (e.g., Fig. 3c), but only significant over the (a)

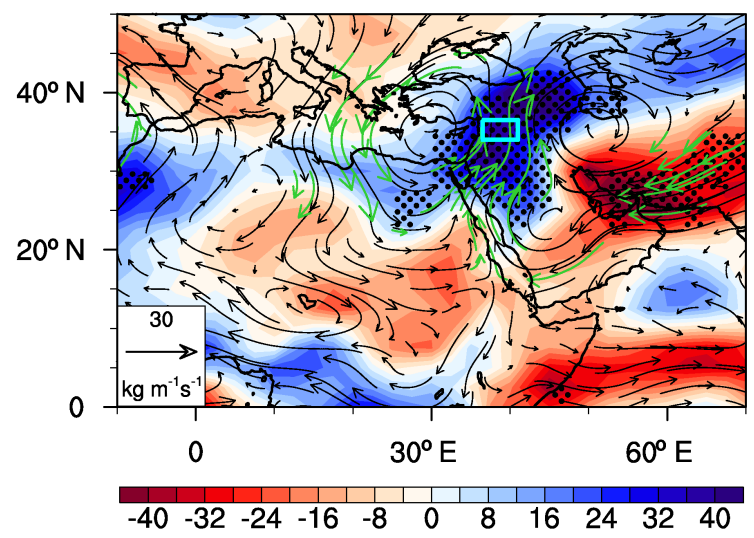

(b) CAPE and UV850 (>1SD)

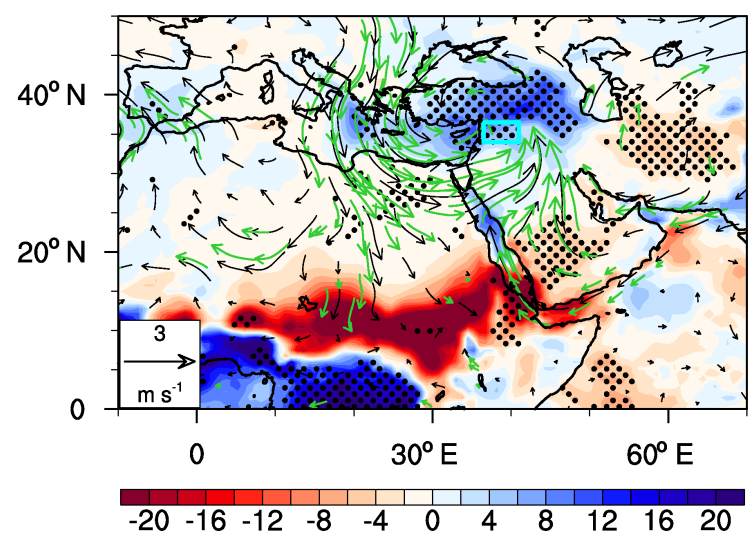

Figure 12. Composites of (a) vertically integrated mass-weighted moisture flux (vectors; $\mathrm{kg} \mathrm{m}^{-1} \mathrm{~s}^{-1}$ ) and its magnitude (shading) from the NCEP1 and (b) CAPE $\left(10 \mathrm{~J} \mathrm{~kg}^{-1}\right)$ along with $850 \mathrm{hPa}$ winds $\left(\mathrm{m} \mathrm{s}^{-1}\right)$ from the ERA-Interim for the days with Syrian DOD index (Aqua) greater than 1 standard deviation during MAM from 2003 to 2015 . Moisture flux is integrated from surface to $300 \mathrm{hPa}$. Shading areas significant at the $95 \%$ confidence level are dotted.

northern North Pacific, indicting a weaker such connection in the model. Over land, DOD is highly positively associated with surface temperature in northern to northeastern Africa, which is not seen in the observations, and may suggest an overestimation of the connection in the model. The correlation pattern is similar if calculated from 1951 to 2010, but with a slightly stronger positive correlation over the tropical eastern Pacific (not shown).

Figure 13b shows the regression of standardized DOD index onto $200 \mathrm{hPa}$ (contours) and $850 \mathrm{hPa}$ geopotential heights (shading) during MAM 1960-2010. The wave trains propagation from the north Pacific to the Middle East is quite similar to that shown in the NCEP1 using the observed DOD index (Fig. 4b and d) but in a weaker magnitude in the tropical and subtropical North Pacific, consistent with the weak SST correlations (Fig. 13a). The anomalous low over Africa dips down to the eastern Sahel, probably in association with 


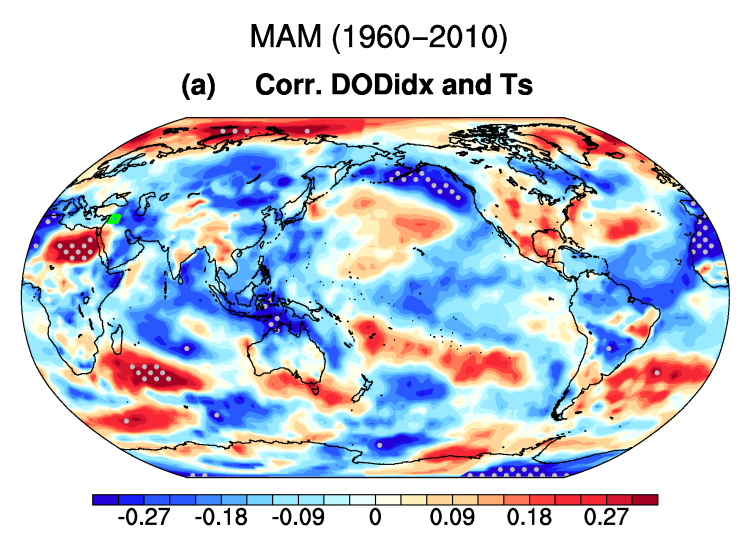

(b) Reg. stdDODidx and $z 850$

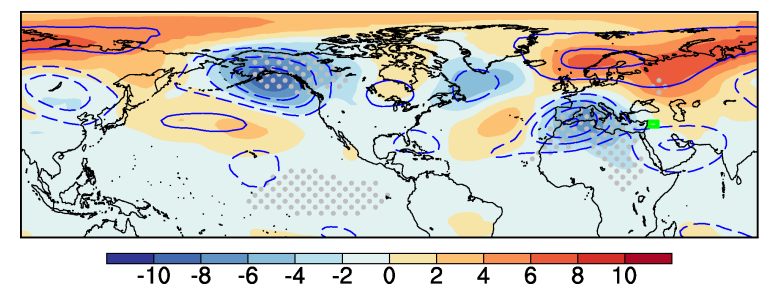

Figure 13. (a) Correlation between AM3 DOD index averaged over Syria (see Fig. 2) and surface temperature from 1960 to 2010 and (b) regression of $850 \mathrm{hPa}$ (shading) and $200 \mathrm{hPa}$ (contours; solid lines for positive values and dashed lines for negative values, from -20 to $20 \mathrm{gpm}$ with intervals of $5 \mathrm{gpm}$, zero line is not shown) geopotential height onto the standardized DOD index from 1960 to 2010 . Shading areas significant at the $95 \%$ confidence level are dotted.

the biased correlation between the DOD and surface temperature over northeastern Africa.

Figure 13 suggests that AM3 can partially capture the connection between the dust activities in Syria and the PDO during 1960-2010. This complements our satellite observationbased analysis on their relationship in the recent decade, although the modeled relationship is weaker than that in the observations. A few reasons may contribute to this underestimation. Firstly, AOD is slightly underestimated in the Middle East in the model compared with AERONET, and the simulated DOD is also less than that in MODIS, which indicates that dust variability may be underestimated in the region. Secondly, the current dust scheme in AM3 only relates dust emission to dust source map and surface wind speed, while the influence of soil moisture on dust emission is not explicitly considered. Thus, the anomalous dust transport from southern Arabian Peninsula and northeast Africa in association with the dry conditions under a negative PDO may not be fully captured by the model. Our analysis also suggests that the DOD in the model is highly correlated with dry deposition over the western Mediterranean, along the north coast of Egypt, and over Turkey and is also correlated with the southwesterly winds in this region, indicating a very strong connection with the dust sources in Africa, which may be an overestimation. However, it is not uncommon for global or regional climate models to have difficulties capturing the interannual to decadal variations of dust aerosols (e.g., Evan et al., 2014; Solmon et al., 2015). This is why we did not choose the climate model as a major tool to examine the connection between the PDO and Syrian DOD in this work. A new dust emission scheme that considers the influences of soil moisture and vegetation cover and land use changes is currently under development, and the relationship between Syrian DOD and PDO is likely to be better represented in this newer version of the GFDL model.

\section{Conclusions}

Dust activities in the Middle East have been related to many factors, such as remote sea surface temperatures, nearsurface winds, vegetation coverage, and precipitation variability. The ongoing civil war and a recent severe dust storm in Syria in 2015 raised concerns as to whether dust activities will increase in the region. The first step toward answering this question is to understand the dust activities driven by the natural climate variability. Here we examine the connection between Syrian dust activities and the Pacific Decadal Oscillation using innovative dust optical depth datasets retrieved from MODIS Deep Blue aerosol products and multiple observations and reanalyses.

A significantly negative correlation is found between Syrian DOD and the PDO in springtime during 2003-2015, suggesting that the PDO index explains about $81 \%$ variances of Syrian DOD in spring in the recent decade. Such a connection is revealed not only by precipitation as emphasized by previous studies (e.g., Yu et al., 2014; Notaro et al., 2015) but also on other aspects such as the circulation patterns and surface winds. It is found that high DOD in Syria during spring is associated with low geopotential height over Europe, the southern Arabian Peninsula, and northeastern to eastern Africa. Associated with these anomalous height patterns are the westerly wind anomalies over the Mediterranean basin and southerly wind anomalies over the southeastern Arabian Peninsula, favoring dust transport from these regions to Syria, where the transported dust dominates the DOD in spring (Ginoux, 2015). A positive PDO is connected with wind and height patterns largely opposite to those associated with high DOD over Syria. The positive phase of the PDO also tends to increase precipitation over the Arabian Peninsula and northeastern Africa via anomalous moisture transport that increases moisture supply and also reduces the stability of low-level atmosphere. A negative PDO thus is not only associated with wind and geopotential height patterns favorable to high DOD in Syria but also tends to reduce precipitation in the dust source regions such as Iraq, Saudi Arabia, and northeastern Africa, and thus favors dust 
transport to Syria. This explains why the correlation between the Syrian DOD index and the PDO index is much higher than other individual index such as precipitation, leaf area index, and $10 \mathrm{~m}$ winds in Syria (Tables 1-2). The influences of the PDO on circulation and precipitation patterns over the Middle East largely persist beyond the recent decade, e.g., over 1948-2015, but also show some exceptions. The lack of long-term observations also brings uncertainties to the connection between the PDO and Syrian DOD.

Unlike the patterns on seasonal mean discussed above, analysis on the daily composites of strong spring dust storms shows the influence of both the PDO and local features. In spring, strong dust storms (DOD anomalies greater than 1 standard deviation) in Syria are associated with an anomalous cyclonic flow centered over the northeastern Mediterranean Sea and Turkey, and southerly wind anomalies from the Red Sea and Persian Gulf. Consistently, moisture flux onto Turkey and Syria is enhanced and thus destabilizes the atmosphere and promotes precipitation in Turkey and convection and dust uplifting in Syria. Meanwhile, reduced moisture fluxes onto the southern Arabian Peninsula, east coast of Egypt, and the Republic of the Sudan (in association with a negative PDO) favor a dry and stable condition in Saudi Arabia and northeastern Africa, facilitating dust transport from these regions to Syria.

We examined the teleconnection between Syrian DOD and the PDO in the GFDL AM3 model. A weaker connection compared to that in the observation is found, which may be partially related to the model's underestimation of the mean DOD and its variability in this area. The new dust scheme that includes the influence of soil moisture and precipitation is likely to overcome these drawbacks and provide a better representation of the relationship between Syrian DOD and the PDO.

\section{Data availability}

PRECL Precipitation data are provided by the NOAA/OAR/ESRL PSD, Boulder, Colorado, USA, from their website at http://www.esrl.noaa.gov/psd/. PDO and Niño 3.4 indices are downloaded from the website of NOAA Climate Prediction Center (http://www.esrl.noaa.gov/psd/data/climateindices/list/).

The NCEP/NCAR reanalysis product was obtained from http://www.esrl.noaa.gov/psd/data/gridded/data.ncep.

reanalysis.html, and the ERA-Interim is downloaded from http://www.ecmwf.int/en/research/climate-reanalysis/

era-interim. HadISST is downloaded from http: //www.metoffice.gov.uk/hadobs/hadisst/data/download.html while CRU TS 3.23 temperature and precipitation are downloaded from https://crudata.uea.ac.uk/cru/data/hrg/ cru_ts_3.23/cruts.1506241137.v3.23/. The MODIS Deep Blue aerosol products were acquired from the Level-1 and Atmosphere Archive and Distribution System (LAADS)
Distributed Active Archive Center (DAAC), located in the Goddard Space Flight Center in Greenbelt, Maryland (https://ladsweb.nascom.nasa.gov/).

\section{The Supplement related to this article is available online at doi:10.5194/acp-16-13431-2016-supplement.}

Acknowledgements. This research was supported by NOAA, Princeton University's Cooperative Institute for Climate Science, and NASA under grants NNG14HH42I-MAP and NNH14ZDA001N-ACMAP. Comments and suggestions from the reviewers improved the paper and are gratefully appreciated.

Edited by: E. Gerasopoulos

Reviewed by: two anonymous referees

\section{References}

Alexander, M. A., Bladé, I., Newman, M., Lanzante, J. R., Lau, N.-C., and Scott, J. D.: The atmospheric bridge: The influence of ENSO teleconnections on air-sea interaction over the global oceans, J. Climate, 15, 2205-2231, doi:10.1175/15200442(2002)015<2205:TABTIO>2.0.CO;2, 2002.

Anderson, T. L., Wu, Y., Chu, D. A., Schmid, B., Redemann, J., and Dubovik, O.: Testing the MODIS satellite retrieval of aerosol fine-mode fraction, J. Geophys. Res., 110, D18204, doi:10.1029/2005JD005978, 2005.

Banerjee, P. and Kumar, S. P.: ENSO modulation of interannual variability of dust aerosols over the northwest Indian Ocean, J. Climate, 29, 1287-1303, doi:10.1175/JCLI-D-15-0039.1, 2016.

Bangert, M., Nenes, A., Vogel, B., Vogel, H., Barahona, D., Karydis, V. A., Kumar, P., Kottmeier, C., and Blahak, U.: Saharan dust event impacts on cloud formation and radiation over Western Europe, Atmos. Chem. Phys., 12, 4045-4063, doi:10.5194/acp-124045-2012, 2012.

Barlow, M., Cullen, H., and Lyon, B.: Drought in central and southwest Asia: La Niña, the warm pool, and Indian Ocean precipitation, J. Climate, 15, 697-700, doi:10.1175/15200442(2002)015,0697:DICASA.2.0.CO;2, 2002.

Chakraborty, A., Behera, S. K., Mujumdar, M., Obha, R., and Yamagata, T.: Diagnosis of tropospheric moisture over Saudi Arabia and influence of IOD and ENSO, Mon. Weather Rev., 134, 598617, 2006.

Chen, M., Xie, P., Janowiak, J. E., and Arkin, P. A.: Global Land Precipitation: A 50-yr Monthly Analysis Based on Gauge Observations, J. Hydrometeorol., 3, 249-266, doi:10.1175/15257541(2002)003<0249:GLPAYM>2.0.CO;2, 2002.

Chin, M., Diehl, T., Tan, Q., Prospero, J. M., Kahn, R. A., Remer, L. A., Yu, H., Sayer, A. M., Bian, H., Geogdzhayev, I. V., Holben, B. N., Howell, S. G., Huebert, B. J., Hsu, N. C., Kim, D., Kucsera, T. L., Levy, R. C., Mishchenko, M. I., Pan, X., Quinn, P. K., Schuster, G. L., Streets, D. G., Strode, S. A., Torres, O., and Zhao, X.-P.: Multi-decadal aerosol variations from 1980 to 2009: a perspective from observations and a global model, Atmos. Chem. Phys., 14, 3657-3690, doi:10.5194/acp-14-3657-2014, 2014. 
Choobari, O. A., Zawar-Reza, P., and Sturman, A.: The global distribution of mineral dust and its impacts on the climate system: A review, Atmos. Res., 138, 152-165, doi:10.1016/j.atmosres.2013.11.007, 2014.

Claverie, M., Vermote, E., and NOAA CDR Program: NOAA Climate Data Record (CDR) of Leaf Area Index (LAI) and Fraction of Absorbed Photosynthetically Active Radiation (FAPAR), Version 4, NOAA National Climatic Data Center, doi:10.7289/V5M043BX, 2014.

Claverie, M., Matthews, J. L., Vermote, E. F., and Justice, C. O.: A $30+$ year AVHRR LAI and FAPAR climate data record: Algorithm description and validation, Remote Sens., 8, 263, doi:10.3390/rs8030263, 2016.

Dai, A.: The influence of the inter-decadal Pacific oscillation on US precipitation during 1923-2010, Clim. Dynam., 41, 633-646, doi:10.1007/s00382-012-1446-5, 2013.

D'Almeida, G. A.: Desert aerosol characteristics and effects on climate, in: Palleoclimatology and Paleometeorology: Modern and Past patterns of Global Atmospheric Transport, edited by: Lienen, M. and Sarnthein, M., Kluwer Academic Publishers, 311-338, 1989.

Dayan, U.: Climatology of back trajectories from Israel based synoptic analysis, J. Climate Appl. Meteor., 25, 591-595, 1986.

Dayan, U., Ziv, B., Shoob, T., and Enzel, Y.: Suspended dust over southeastern Mediterranean and its relation to atmospheric circultions, Int. J. Climatol., 28, 915-924, doi:10.1002/joc.1587, 2008.

Dayan, U., Tubi, A., and Levy, I.: On the importance of synoptic classification methods with respect to environmental phenomena, Int. J. Climatol., 32, 681-694, doi:10.1002/joc.2297, 2012.

Dee, D.P., Uppala, S. M., Simmons, A. J., Berrisford, P., Poli, P., Kobayashi, S., Andrae, U., Balmaseda, M. A., Balsamo, G., Bauer, P., Bechtold, P., Beljaars, A. C. M., van de Berg, L., Bidlot, J., Bormann, N., Delsol, C., Dragani, R., Fuentes, M., Geer, A. J., Haimberger, L., Healy, S. B., Hersbach, H., Hölm, E. V., Isaksen, L., Kållberg, P., Köhler, M., Matricardi, M., McNally, A. P., Monge-Sanz, B. M., Morcrette, J.-J., Park, B.-K., Peubey, C., de Rosnay, P., Tavolato, C., Thépaut, J.-N., and Vitart, F.: The ERA-Interim reanalysis: configuration and performance of the data assimilation system, Q. J. Roy. Meteor. Soc., 137, 553-597, doi:10.1002/qj.828, 2011.

Dempsey, M. J.: Forecasting strategies for Haboobs: an underreported weather phenomenon, Adv. Meteorol., 904759, 1-6, doi:10.1155/2014/904759, 2014.

Deser, C. and Blackmon, M. L.: On the relationship between tropical and North Pacific sea surface temperature variations, J. Climate, 8, 1677-1680, doi:10.1175/15200442(1995)008<1677:OTRBTA>2.0.CO;2, 1995.

Donner, L., Wyman, B. L., Hemler, R. S, Horowitz, L. W., Ming, Y., Zhao, M., Golaz, J.-C., Ginoux, P., Lin, S.-J., Schwarzkopf, M. D., Austin, J., Alaka, G., Cooke, W. F., Delworth, T. L., Freidenreich, S. M., Gordon, C. T., Griffies, S. M., Held, I. M., Hurlin, W. J., Klein, S. A., Knutson, T. R., Langenhorst, A. R., Lee, H.C., Lin, Y., Magi, B. I., Malyshev, S. L., Milly, P. C. D., Naik, V., Nath, M. J., Pincus, R., Ploshay, J. J., Ramaswamy, V., Seman, C. J., Shevliakova, E., Sirutis, J. J., Stern, W. F., Stouffer, R. J., Wilson, R. J., Winton, M., Wittenberg, A. T., and Zeng, F.: The dynamical core, physical parameterizations, and basic simulation characteristics of the atmospheric component AM3 of the GFDL global coupled model CM3, J. Climate, 24, 3484-3519, 2011.

Eck, T. F., Holben, B. N., Reid, J. S., Dubovik, O., Smirnov, A., O’Neill, N. T., Slutsker, I., and Kinne, S.: Wavelength dependence of the optical depth of biomass burning, urban, and desert dust aerosols, J. Geophys. Res., 104, 31333-31349, doi:10.1029/1999JD900923, 1999.

Evan, A. T., Flamant, C., Fiedler, S., and Doherty, O.: An analysis of aeolian dust in climate models, Geophys. Res. Lett., 41, 59966001, doi:10.1002/2014GL060545, 2014.

Evans, M. N., Cane, M. A., Schrag, D. P. , Kaplan, A., Linsley, B. K., Villalba, R., and Wellington, G. M.: Support for tropically-driven Pacific decadal variability based on paleoproxy evidence, Geophys. Res. Lett., 28, 3689-3691, doi:10.1029/2001GL013223, 2001.

Fung, I., Meyn, S., Tegen, I., Doney, S. C., John, J., and Bishop, J. K. B.: Iron supply and demand in the upper ocean, Global Biogeochem. Cy., 14, 281-296, doi:10.1029/1999GB900059, 2000.

Ginoux, P.: The origin of modern day dust deposition in Negev: a modeling study, The Batsheva de Rothschild Seminar on Atmospheric Dust, Dust Deposits (Loess) and Soils in Deserts and Desert Fringe, Jerusalem and Negev, Israel, 2015.

Ginoux, P., Chin, M., Tegen, I., Prospero, J. M., Holben, B., Dubovik, O., and Lin, S.-J.: Sources and distributions of dust aerosols simulated with the GOCART model, J. Geophys. Res., 106, 22255-22274, doi:10.1029/2000JD000053, 2001.

Ginoux, P., Garbuzov, D., and Hsu, H. C.: Identification of anthropogenic and natural dust sources using Moderate Resolution Imaging Spectroradiometer (MODIS) Deep Blue level 2 data, J. Geophys. Res., 115, D05204, doi:10.1029/2009JD012398, 2010.

Ginoux, P., Prospero, J. M., Gill, T. E., Hsu, N. C., and Zhao, M.: Global-scale attribution of anthropogenic and natural dust sources and their emission rates based on the MODIS Deep Blue aerosol products, Rev. Geophys., 50, RG3005, doi:10.1029/2012RG000388, 2012.

Harris, I., Jones, P. D., Osborn, T. J., and Lister, D. H.: Updated high-resolution grids of monthly climatic observations - the CRU TS3.10 Dataset, Int. J. Climatol., 34, 623-642, doi:10.1002/joc.3711, 2014.

Hsu, N. C., Tsay, S.-C., King, M., and Herman, J. R.: Aerosol properties over bright-reflecting source regions, IEEE Trans. Geosci. Remote Sens., 42, 577-569, doi:10.1109/TGRS.2004.824067, 2004.

Hsu, N. C., Tsay, S.-C. , King, M., and Herman, J. R.: Deep blue retrievals of Asian aerosol properties during ACEAsia, IEEE Trans. Geosci. Remote Sens., 44, 3180-3195, doi:10.1109/TGRS.2006.879540, 2006.

Huang, B., Banzon, V. F., Freeman, E., Lawrimore, J., Liu, W., Peterson, T. C., Smith, T. M., Thorne, P. W., Woodruff, S. D., and Zhang, H.-M.: Extended Reconstructed Sea Surface Temperature version 4 (ERSST.v4): Part I. Upgrades and intercomparisons, J. Climate, 28, 911-930, doi:10.1175/JCLI-D-14-00006.1, 2015.

Huang, B., Thorne, P., Smith, T., Liu, W., Lawrimore, J., Banzon, V., Zhang, H., Peterson, T., and Menne, M.: Further Exploring and Quantifying Uncertainties for Extended Reconstructed Sea Surface Temperature (ERSST) Version 4 (v4), J. Climate, 29, 3119-3142, doi:10.1175/JCLI-D-15-0430.1, 2016.

Huang, J., Wang, T., Wang, W., Li, Z., and Yan, H.: Climate effects of dust aerosol over East Asian arid and semi- 
arid regions, J. Geophys. Res.-Atmos., 119, 11398-11416, doi:10.1002/2014JD21796, 2014.

Huffman, G. J. and Bolvin, D. T.: TRMM and other data precipitation data set documentation. TRMM Doc., 42 pp., available at: ftp://meso-a.gsfc.nasa.gov/pub/trmmdocs/3B42_3B43_ doc.pdf (last access: August 2016), 2014.

Israelevich, P. L., Ganor, E., Levin, Z., and Joseph, J. H.: Annual variations of physical properties of desert dust over Israel, J. Geophys. Res., 180, 4381, doi:10.1029/2002JD003163, 2003.

Jin, Q., Wei, J., and Yang, Z.-L.: Positive response of indian summer rainfall to middle east dust, Geophys. Res. Lett., 41, 4068-4074, doi:10.1002/2014g1059980, 2014.

Jin, Q., Wei, J., Yang, Z.-L., Pu, B., and Huang, J.: Consistent response of Indian summer monsoon to Middle East dust in observations and simulations, Atmos. Chem. Phys., 15, 9897-9915, doi:10.5194/acp-15-9897-2015, 2015.

Jin, Q., Yang, Z.-L., and Wei, J.: Seasonal Responses of Indian Summer Monsoon to Dust Aerosols in the Middle East, India, and China, J. Climate, 29, 6329-6349, doi:10.1175/JCLI-D-150622.1, 2016.

Kalnay, E., Kanamitsu, M., Kistler, R., W. Collines, Deaven, D., Gandin, L., Iredell, M., Saha, S., White, G., Woollen, J., Zhu, Y., Leetmaa, A., Reynolds, R., Chelliah, M., Ebisuzaki, W., Higgins, W., Janowiak, J., Mo, K. C., Ropelewski, C., and Wang, J.: The NCEP/NCAR 40-year reanalysis project, B. Am. Meteorol. Soc., 77, 437-471, doi:10.1175/15200477(1996)077<0437:Tnyrp>2.0.Co;2, 1996.

Kim, M.-K., Lau, W. K. M., Kim, K.-M., Sang, J., Kim, Y.-H., and Lee, W.-S.: Amplification of ENSO effects on Indian summer monsoon by absorbing aerosols, Clim. Dynam., 46, 2657-2671, doi:10.1007/s00382-015-2722-y, 2016.

Klingmüller, K., Pozzer, A., Metzger, S., Stenchikov, G. L., and Lelieveld, J.: Aerosol optical depth trend over the Middle East, Atmos. Chem. Phys., 16, 5063-5073, doi:10.5194/acp-16-50632016, 2016.

Kubilay, N., Nickovic, S., Moulin, C., and Dulac, F.: An illustration of the transport and deposition of mineral dust onto the eastern Mediterranean, Atmos. Environ., 34, 1293-1303, doi:10.1016/S1352-2310(99)00179-X, 2000

Lau, K. M., Kim, K. M., Sud, Y. C., and Walker, G. K.: A GCM study of the response of the atmospheric water cycle of West Africa and the Atlantic to Saharan dust radiative forcing, Ann. Geophys., 27, 4023-4037, doi:10.5194/angeo-27-40232009, 2009.

Levin, Z., Ganor, E., and Gladstein, V.: The effects of desert particles coated with sulfate on rain formation in the eastern Mediterranean, J. Appl. Meteor., 35, 1511-1523, doi:10.1175/15200450(1996)0351511:TEODPC.2.0.CO;2, 1996.

Li, F., Ginoux, P., and Ramaswamy, V.: Distribution, transport, and deposition of mineral dust in the Southern Ocean and Antarctica: Contribution of major sources, J. Geophys. Res., 113, D10207, doi:10.1029/2007JD009190, 2008.

Lin, S.-J.: A finite-volume integration method for computing pressure-gradient force in general vertical coordinates, Q. J. Roy. Meteor. Soc., 123, 1749-1762, doi:10.1002/qj.49712354214, 1997.

Lin, S.-J.: A "vertically Lagrangian" finite-volume dynamical core for global models, Mon. Weather Rev., 132, 2293-2307,
doi:10.1175/1520-0493(2004)132<2293:AVLFDC>2.0.CO;2, 2004.

Lin, S.-J. and Rood, R. B.: Multidimensional flux-form semiLagrangian transport schemes, Mon. Weather Rev., 124, 20462070, 1996.

Lin, S.-J. and Rood, R. B.: An explicit flux-form semiLagrangian shallow water model on the sphere, Q. J. Roy. Meteor. Soc., 123, 2477-2498, doi:10.1175/15200493(1996)124<2046:MFFSLT>2.0.CO;2, 1997.

Liu, W., Huang, B., Thorne, P. W., Banzon, V. F., Zhang, H.M., Freeman, E., Lawrimore, J., Peterson, T. C., Smith, T. M., and Woodruff, S. D.: Extended Reconstructed Sea Surface Temperature version 4 (ERSST.v4): Part II. Parametric and structural uncertainty estimations, J. Climate, 28, 931-951, doi:10.1175/JCLI-D-14-00007.1, 2015.

Liu, Z. and Alexander, M.: Atmospheric bridge, oceanic tunnel, and global climatic teleconnections, Rev. Geophys., 45, RG2005, doi:10.1029/2005RG000172, 2007.

Mahowald, N. M., Kloster, S., Engelstaedter, S., Moore, J. K., Mukhopadhyay, S., McConnell, J. R., Albani, S., Doney, S. C., Bhattacharya, A., Curran, M. A. J., Flanner, M. G., Hoffman, F. M., Lawrence, D. M., Lindsay, K., Mayewski, P. A., Neff, J., Rothenberg, D., Thomas, E., Thornton, P. E., and Zender, C. S.: Observed 20th century desert dust variability: impact on climate and biogeochemistry, Atmos. Chem. Phys., 10, 10875-10893, doi:10.5194/acp-10-10875-2010, 2010.

Mantua, H. and Hare, S. R.: The Pacific Decadal Oscillation, J. Oceanogr., 58, 35-44, 2002.

Mariotti, A.: How ENSO impacts precipitation in southwest central Asia, Geophys. Res. Lett., 34, L16706, doi:10.1029/ 2007GL030078, 2007.

Mariotti, A., Ballabrera-Poy, J., and Zeng, N.: Tropical influence on Euro-Asian autumn rainfall variability, Clim. Dynam., 24, 511521, doi:10.1007/s00382-004-0498-6, 2005.

Miller, R. L. and Tegen, I.: Climate response to soil dust aerosols, J. Climate, 11, 3247-3267, doi:10.1175/15200442(1998)011<3247:CRTSDA>2.0.CO;2, 1998.

Miller, R. L., Tegen, I., and Perlwitz, J.: Surface radiative forcing by soil dust aerosols and the hydrologic cycle, J. Geophys. Res., 109, D04203, doi:10.1029/2003JD004085, 2004.

Miller, S., Kuciauskas, A. P., Liu, M., Ji, Q., Reid, J. S., Breed, D. W., Walker, A. L., and Mandoos, A. A.: Haboob dust storms of the southern Arabian Peninsula, J. Geophys. Res., 113, D01202, doi:10.1029/2007JD008550, 2008.

Mills, C. M. and Walsh, J. E.: Seasonal variation and spatial patterns of the atmospheric component of the Pacific decadal oscillation, J. Climate, 26, 1575-1594, doi:10.1175/JCLI-D-1200264.1, 2013

Minobe, S.: A 50-70 year climate oscillation over the North Pacific and North America, Geophys. Res. Lett., 24, 683-686, doi:10.1029/97GL00504, 1997.

Moorthi, S. and Suarez, M. J.: Relaxed Arakawa-Schubert. A parameterization on moist convection for general circulation models, Mon. Weather Rev., 120, 978-1002, 1992.

Morman, S. A. and Plumlee, G. S.: The role of airborne mineral dusts in human disease, Aeolian Res., 9, 203-212, doi:10.1016/j.aeolia.2012.12.001., 2013. 
Moulin, C., Lambert, C. E., Dulac, F., and Dayan, U.: Control of atmospheric export of dust from North Africa by the North Atlantic oscillation, Nature, 387, 691-694, 1997.

Nakajima, T., Higurashi, A., Kawamoto, K., and Penner, J. E.: A possible correlation between satellite-derived cloud and aerosol microphysical parameters, Geophys. Res. Lett., 28, 1171-1174, doi:10.1029/2000GL012186, 2001.

Newman, M., Compo, G. P., and Alexander, M.: ENSOforced variability of the Pacific decadal oscillation, J. Climate, 16, 3853-3857, doi:10.1175/15200442(2003)016<3853:EVOTPD>2.0.CO;2, 2003.

Notaro, M., Alkolibi, F., Fadda, E., and Bakhrjy, F.: Trajectory analysis of Saudi Arabian dust storms, J. Geophys. Res. Atmos., 118, 6028-6043, 2013.

Notaro, M., Yu, Y., and Kalashnikova, O. V.: Regime shift in Arabian dust activity, triggered by persistent Fertile Crescent drought, J. Geophys. Res.-Atmos., 120, 10229-10249, doi:10.1002/2015JD023855, 2015.

Pozzer, A., de Meij, A., Yoon, J., Tost, H., Georgoulias, A. K., and Astitha, M.: AOD trends during 2001-2010 from observations and model simulations, Atmos. Chem. Phys., 15, 5521-5535, doi:10.5194/acp-15-5521-2015, 2015.

Price, C., Stone, L., Huppert, A., Rajagopalan, B., and Alpert, P.: A possible link between El Niño and precipitation in Israel, Geophys. Res. Lett., 25, 3963-3966, doi:10.1029/1998GL900098, 1998.

Rayner, N. A., Parker, D. E., Horton, E. B., Folland, C. K., Alexander, L. V., Rowell, D. P., Kent, E. C., and Kaplan, A.: Global analyses of sea surface temperature, sea ice, and night marine air temperature since the late nineteenth century, J. Geophys. Res., 108, 4407, doi:10.1029/2002JD002670, 2003.

Roberts, A. and Knippertz, P.: Haboobs: convectively generated dust storms in West Africa, Weather, 67, 311-316, 2012.

Rosenfeld, J. E., Considine, D. B., Meade, P. E., Bacmeister, J. T., Jackman, C. H., and Schoeberl, M. R.: Stratospheric effects of Mount Pinatubo aerosol studied with a coupled two-dimensional model, J. Geophys. Res., 102, 3649-3670, doi:10.1029/96JD03820, 1997.

Schneider, N. and Cornuelle, B.: The forcing of the Pacific decadal oscillation, J. Climate, 18, 4355-4373, 2005.

Shao, Y., Wyrwoll, K.-H., and Chappell, A., Huang, J., Lin, Z., McTainsh, G. H., Mikami, M., Tanaka, T. Y., Wang, X., and Yoon, S.: Dust cycle: an emerging core theme in Earth system science, Aeolian Res., 2, 181-204, doi:10.1016/j.aeolia.2011.02.001, 2011.

Simmons, A. J. and Burridge, D. M.: An energy and angularmomentum conserving vertical finite-difference scheme and hybrid vertical coordinates, Mon. Weather Rev., 109, 758-766, doi:10.1175/1520-0493(1981)109<0758:AEAAMC>2.0.CO;2, 1981.

Solmon, F., Mallet, M., Elguindi, N., Giorgi, F., Zakey, A., and Konaré, A.: Dust aerosol impact on regional precipitation over western Africa, mechanisms and sensitivity to absorption properties, Geophys. Res. Lett., 35, L24705, doi:10.1029/2008GL035900, 2008.

Solmon, F., Elguindi, N., and Mallet, M.: Radiative and climatic effects of dust over West Africa, as simulated by a regional climate model, Climate Res., 52, 97-113, doi:10.3354/cr01039, 2012.
Solmon, F., Nair, V. S., and Mallet, M.: Increasing Arabian dust activity and the Indian summer monsoon, Atmos. Chem. Phys., 15, 8051-8064, doi:10.5194/acp-15-8051-2015, 2015.

Strong, C. and Magnusdottir, G.: The role of tropospheric Rossby wave breaking in the Pacific decadal oscillation, J. Climte, 22, 1819-1833, doi:10.1175/2008JCLI2593.1, 2009.

Strong, J. D. O., Vecchi, G. A., and Ginoux, P.: The response of the tropical Atlantic and West African climate to Saharan dust in a fully coupled GCM, J. Climate, 28, 7071-7092, doi:10.1175/JCLI-D-14-00797.1, 2015.

Tegen, I., Lacis, A., and Fung, I.: The influence of mineral aerosol from disturbed soils on the global radiation budget, Nature, 380, 419-422, doi:10.1038/380419a0, 1996.

Vinoj, V., Rasch, P. J., Wang, H. L., Yoon, J. H., Ma, P. L., Landu, K., and Singh, B.: Short-term modulation of Indian summer monsoon rainfall by West Asian dust, Nat. Geosci., 7, 308-313, 2014.

Vukovic, A., Vujadinovic, M., Pejanovic, G., Andric, J., Kumjian, M. R., Djurdjevic, V., Dacic, M., Prasad, A. K., El-Askary, H. M., Paris, B. C., Petkovic, S., Nickovic, S., and Sprigg, W. A.: Numerical simulation of "an American haboob", Atmos. Chem. Phys., 14, 3211-3230, doi:10.5194/acp-14-3211-2014, 2014.

Wang, S., Huang, J., He, Y., and Guan, Y.: Combined effects of the Pacific Decadal Oscillation and El Niño-Southern Oscillation on global land dry-wet changes, Sci. Rep., 4, 6651, doi:10.1038/srep06651, 2014.

Wurzler, S. C., Reisin, T. G., and Levin, Z.: Modification of mineral dust particles by cloud processing and subsequent effects on drop size distributions, J. Geophys. Res., 105, 4501-4512, doi:10.1029/1999JD900980, 2000.

Yoshioka, M., Mahowald, N. M., Conley, A. J., Collins, W. D., Fillmore, D. W., Zender, C. S., and Coleman, D. B.: Impact of desert dust radiative forcing on Sahel precipitation: Relative importance of dust compared to sea surface temperature variations, vegetation changes, and greenhouse gas warming, J. Climate, 20, 14451467, doi:10.1175/JCLI4056.1, 2007.

Yu, Y., Notaro, M., Liu, Z., Wang, F., Alkolibi, F., Fadda, E., and Bakhrjy, F.: Climatic controls on the interannual to decadal variability in Saudi Arabian dust activity: Toward the development of a seasonal dust prediction model, J. Geophys. Res.-Atmos., 120, 1739-1758, doi:10.1002/2014JD022611, 2015.

Yue, X., Wang, H., Liao, H., and Fan, K.: Direct climatic effect of dust aerosol in the NCAR Community Atmosphere Model version 3 (CAM3), Adv. Atmos. Sci., 27, 230-242, doi:10.1007/s00376-009-8170-z, 2010.

Yue, X., Liao, H., Wang, H. J., Li, S. L., and Tang, J. P.: Role of sea surface temperature responses in simulation of the climatic effect of mineral dust aerosol, Atmos. Chem. Phys., 11, 60496062, doi:10.5194/acp-11-6049-2011, 2011.

Zhang, L. and Delworth, T.: Analysis of the characteristic and mechanisms of the Pacific decadal oscillation in a suite of coupled models from the Geophysical Fluid Dynamics Laboratory, J. Climate, 28, 7678-7701, doi:10.1175/JCLI-D-14-00647.1, 2015.

Zhang, Y., Wallace, J. M., and Battisti, D. S.: ENSOlike interdecadal variability, J. Climate, 10, 1004-1020, doi:10.1175/1520-0442(1997)010<1004:ELIV>2.0.CO;2, 1997. 